\title{
Conservation and Phylogeography of Plants: From the Mediterranean to the Rest of the World
}

\author{
Javier Bobo-Pinilla ${ }^{1,2, *(\mathbb{D})}$, Esteban Salmerón-Sánchez ${ }^{3}$ (D), Antonio J. Mendoza-Fernández ${ }^{3}$ (D) Juan F. Mota ${ }^{3}$ (D) \\ and Julio Peñas 4 (iD
}

check for updates

Citation: Bobo-Pinilla, J.;

Salmerón-Sánchez, E.;

Mendoza-Fernández, A.J.;

Mota, J.F.; Peñas, J. Conservation

and Phylogeography of Plants: From the Mediterranean to the Rest of the World. Diversity 2022, 14, 78. https:// doi.org/10.3390/d14020078

Academic Editors: Theophanis Constantinidis and Michael Wink

Received: 31 December 2021

Accepted: 20 January 2022

Published: 24 January 2022

Publisher's Note: MDPI stays neutral with regard to jurisdictional claims in published maps and institutional affiliations.

Copyright: (C) 2022 by the authors. Licensee MDPI, Basel, Switzerland. This article is an open access article distributed under the terms and conditions of the Creative Commons Attribution (CC BY) license (https:// creativecommons.org/licenses/by/ $4.0 /)$
1 Department of Botany, University of Salamanca, 37007 Salamanca, Spain

2 Biobanco de ADN Vegetal, Edificio Multiusos I+D+i, 37007 Salamanca, Spain

3 Department of Biology and Geology, CEI·MAR and CECOUAL, University of Almería, 04120 Almería, Spain; esanchez@ual.es (E.S.-S.); amenfer788@gmail.com (A.J.M.-F.); jmota@ual.es (J.F.M.)

4 Department of Botany, University of Granada, 18071 Granada, Spain; jgiles@ugr.es

* Correspondence: javicastronuevo@usal.es

\begin{abstract}
During the last decades, phylogeography has transformed the ways to analyze and understand plant diversity and biogeography. The repeated and increasingly detailed articles made from DNA data with phylogeographical procedures and algorithms have revolutionized biodiversity research, particularly on biodiversity conservation. This paper presents a systematic literature review of the different ways in which phylogeography has been applied to plants in Mediterranean-type ecosystems (MTEs), especially to rare, threatened, and endemic plants. Studies ranged from basic research to how phylogeography is actually contributing to management conservation of Mediterranean plants. Finally, new and future phylogeography perspectives with integrative scientific arguments and conceptual bases applied to plant conservation biology are discussed.
\end{abstract}

Keywords: ecological niche modelling; endemic plant species; Mediterranean biome; molecular markers; rare and threatened plants

\section{Phylogeographical Studies on Plant Species}

Since Avise [1], it is considered that phylogeny and heredity provide a starting point for understanding connections between macroevolution (systematics and paleontology) and microevolution (population genetics) in a new scientific view: phylogeography. Therefore, it was framed in the evolutionary biology field as an approach to analyze the relationship between Earth history, geography, and biodiversity diversification, and it has been growing and developing since [2]. The phylogeographic paradigm provides integrative approaches with the strength to address patterns and processes involved in the biogeographic histories of populations, species, and biotas [3]. Moreover, regarding diversification processes, phylogeny and phylogeography can enlighten how interactions between evolutionary and ecological processes influence diversity at multiple scales [4]. Phylogeography played a relevant role for historical biogeography by analyzing recent evolutionary processes with paleoclimatic events in Earth history or in the association between biological diversification and geological events [3].

Phylogeographic approaches are used to understand plant species' histories and diversification processes, to apply for population biology, systematic or paleoecology, to look for answers on isolated populations by environmental barriers or geographical distances, and to search for population refugees, demographic bottlenecks, or range expansions/contractions. For example, for refugia theory, phylogeography uses spatial patterns of genetic polymorphism sampled from present-day populations to infer population dynamics [5] where higher genetic diversity is expected, including increased relative abundance of endemic and ancestral alleles and less spatial genetic structure despite higher genetic differentiation within refugia [6,7]. 
The current biodiversity crisis and the critical need to manage the biodiversity have led to an increase in interest in biogeographic studies to understand the evolutionary origin of lineages and historical assembly of biotas [8]. The Convention on Biological Diversity (CBD, 1992) accepted that conservation efforts should be prioritized on species considered endangered, and that the basis for biological diversity lies at the genetic level. Within the European Union, there has been a growing interest in restoring ecosystems, for which the use of native species and local materials is highly desirable since local genotypes are generally better adapted to their specific environmental conditions [9].

The changes caused by anthropogenic habitat destruction and fragmentation can have deleterious demographic and genetic consequences [10]. Conservation biology is essential to preserve the evolutionary and functional heritage of biodiversity by the preservation of current genetic diversity and the diversification processes that are taking place at the species level [11,12]. Phylogeography analyzes colonization and expansion histories based on phylogenies of species and supra-species, which results are relevant for units of conservation $[2,13]$. By providing an understanding of different spatial scales patterns and processes of genetic diversifications, phylogeography can provide essential information for evidence-based conservation priorities.

Several genomic tools (AFLPs, plastid DNA sequences, etc.) have been developed to analyze different molecular data in order to understand the geographical variation of genetic diversification and substitution rates at multiple geographical scales. Moreover, the implementation of geospatial-referencing tools such as Geographical Information Systems (GIS) for analysis, mining and visualization of phylogeographic data [14] has been quickly incorporated into phylogeography, as it represents a significant advance. Currently, because of the deep development of genetic sequencing techniques and their cheapening, population and landscape genetics studies, the advances in coalescence theory, and the complexity in GIS-based spatial tools, phylogeographic studies are essential for genetic conservation, offering fundamental information for decision making in biodiversity conservation and managing plans.

To maintain genetic diversity within species and, in practice, to implement strategies to halt genetic erosion and preserve adaptive potential of populations [15], the research needs to focus on the genetic distinctiveness of populations within species. To this effect, population genetics data are essential for both conceptual and applied biodiversity conservation programs [16,17]. Phylogeographic surveys can help to identify relict populations [18] and genetic unit patterns of importance for biodiversity conservation and management (e.g., [19-21], among others). Despite this, Médail and Braumel [22] reported the scarce use of phylogeography to propose conservation plans for threatened endemic plants within the Mediterranean Basin hotspot (only $27 \%$ of studies used the genetic information generated to establish priorities for species conservation, and around $18 \%$ inferred conservation units). To date, most of the phylogeographic studies have not placed much emphasis on establishing plant management and conservation proposals neither in situ nor ex situ.

Given the large number of works related to conservation in general [23] and taking into account that some authors consider it necessary to include a phylogeographic approach for their conservation studies (e.g., [22]), a systematic literature review of how phylogeography has been applied to plant preservation, focusing especially on Mediterranean-type ecosystems (MTEs), has been performed. To preserve the evolutionary potential of the endemic, rare or threatened plant species, we should prioritize the conservation of emblematic populations. Phylogeographic studies should be used in plant conservation genetics, by offering fundamental information for decision making in conservation plans as they describe the geographical distribution of genetic variability among species populations. Our paper reviews the current state and future directions of phylogeography-based conservation, and it claims to develop and apply scientific arguments and conceptual bases to apply in plant conservation biology. From our view, the present review can be useful as a benchmark to set conservation priorities with the aid of phylogeographical approaches in other ecosystems worldwide, where similar conservation concerns such as in present MTEs, exist. 
To perform a systematic review, we searched in Scopus for papers using the keywords "plant conservation", "phylogeography" and "Mediterranean", and the criterion "AND" that forced the results to include the three keywords. Additional papers were gathered by searching the reference lists from the searched papers. The resulting papers were screened by scanning abstracts in order to exclude papers non-plant related, and only research articles were taken into account. A refined search was performed over full articles, and only those that proposed conservation actions regarding phylogeographic patterns were considered. An initial Scopus search with the keywords mentioned resulted in a total of 463 documents, and after the screenings, only 127 (Table A1) met the proposed criteria. Finally, after reviewing the species and the investigated areas, only 78 documents of the total proposed conservation approaches based on phylogeography in MTEs.

\section{The Mediterranean Biome, Phylogeography Studies and Plant Conservation}

MTEs, and the Mediterranean Basin in particular, contain interesting vegetationtypes with high plant diversity and are recognized as biodiversity hotspots [24-27]. This accumulation of diversity is mainly due to the climatic stability of the MTEs [28] that allows relict lineages to persist and diversify $[29,30]$. At the same time, these areas are one of the most densely human populated and diverse biomes in the world [31]. MTEs cover different areas around the world: the Mediterranean Basin, California, central Chile, Cape Region of South Africa, and southwestern Australia. These share an unusual climatic regime of mild wet winters and warm dry summers $[32,33]$ that can exhibit differing patterns of intraannual and interannual variability in precipitation among regions [34]. The MTEs also share biodiversity features, e.g., richness and biodiversity levels similar to some tropical regions, being higher than expected due to their latitude and low primary productivity $[35,36]$, which include interesting patterns and processes in plant diversity [23,37].

The common climatic conditions in MTEs have been selected for plants with similar functional traits, resulting in comparable vegetation types [35,38-40]. Both winterdeciduous and evergreen woodlands and forests are present in all five MTEs regions but are of limited extent in the Cape Region of South Africa, and all regions except southwestern Australia have elements of montane and alpine vegetation [41]. Despite that, evergreen sclerophyll shrublands with a lower layer of annual herbaceous plants and associated perennials, and occasionally to tree species, form the most characteristic natural vegetation of the MTEs. They are named maquis or garriga in the Mediterranean Basin, kwongan in southwestern Australia, fynbos in the Cape Region of South Africa, matorral in Chile, and chaparral in California, of which harbor the greatest diversity of plant species [25,41,42].

As its species have adapted to high habitat specialization and low climatic tolerances [43,44] MTEs are particularly sensitive to different drivers of biodiversity loss [45], and it is estimated to experience the greatest proportional change in biodiversity by 2100 , owing to its sensitivity to land use change and climate [46]. However, they tend to have well-established threat processes such as grazing, land clearing or fire disruption, either produced by natural or anthropogenic causes. These represent important factors in present-day Mediterranean vegetation modelling, which have determined the historical deforestation of vast areas for agronomic use. In addition, the mentioned threat factors could interact with novel risks (introduced species, urban development, natural areas frequentation, etc.); in three Mediterranean study cases (California, Spain, and Western Australia), threats originating from human activities represented more than $80 \%$ of all threat types [47]. Other studies warn of a worsening conservation status of threatened flora in both high mountain and coastal areas in south Spain, an outstanding biodiversity zone within the Mediterranean Basin [48]. Despite this, the five Mediterranean regions have different historical, cultural, social and political contexts and dynamics [28] and experience differences in the magnitude and type of threats to biodiversity [31,49], leading to a long history of comparative research [28] and biome-level approaches to conservation [31,50,51]. 


\section{Phylogeography and Conservation in MTEs}

Pioneering studies applying the discipline of phylogeography in the Mediterranean Biome date back to the late 20th century. The work of Taberlet et al. [52] is noteworthy, since it compares the migration routes of various animal and plant species, in which common tendences between them are observed, as is the fact that this type of data has important implications in the conservation genetics since it is possible to establish areas in which efforts of this kind must be concentrated. According to these authors, the regions of southern Europe are of a greater interest, as most genetic variation is concentrated in these areas due to their refuge role during the ice ages. In the more specific case of its application to the plant world, the investigation published by Comes and Abbott [53] represents an advance in research proposals on gene flow and geographic distance in plants, suggesting that isolation of refugia during worse climatic conditions, and the effects of subsequent colonization events could have an important effect on molding the present genetic structure of the species.

Considering the 463 papers obtained in the first Scopus search and regarding the temporal evolution of the research, the period of 2007-2012 is noteworthy, which seems to represent the moment of acceleration in the number of publications up to 15 documents per year. The trend doubled in 2011-2012, while in the period 2013-2016, the number of publications had been established around 25 documents. From 2017 onward, there have been a maximum of 40 publications directly related to this subject in several years. Eighty-nine percent of the publications correspond to the type of article, mostly in the format of original research work, and only $7 \%$ are review articles, which may indicate the relative youth of this sort of research. Evolution journal published the first paper dealing with the conservation of a Mediterranean plant species from a phylogeographical point of view. However, Molecular Ecology has been the source that has published most of the articles in this discipline in the last 20 years. In other scientific journals such as PLoS ONE, Ecology and Evolution, Plant Systematics and Evolution, Botanical Journal of the Linnean Society, Taxon, American Journal of Botany or Conservation Genetics, more than 10 papers on this topic have been published. To conclude, up to 185 international scientific journals can be counted with at least one article published on this topic (Figure 1).

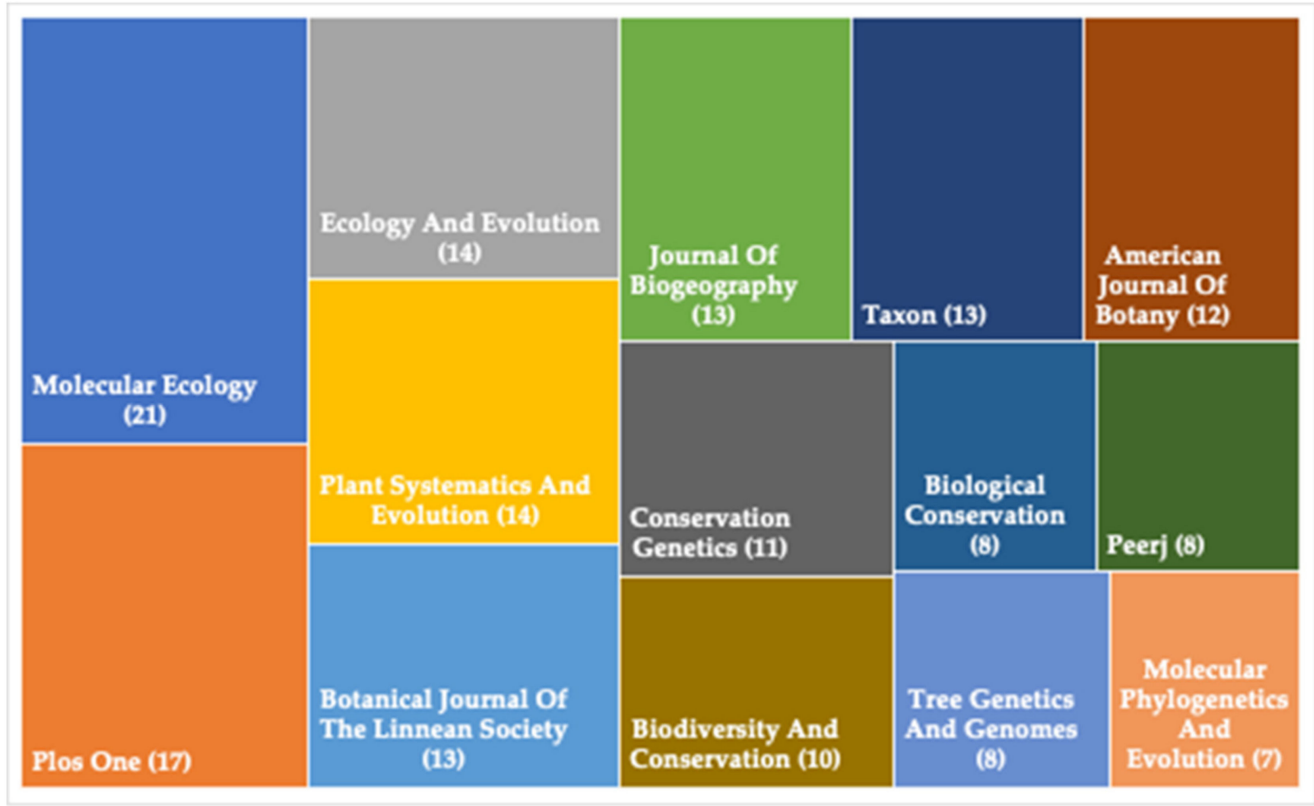

Figure 1. Number of documents per journal regarding the initial Scopus search using the keywords "plant conservation", "phylogeography" and "Mediterranean". Only journals with more than six published papers are shown. 
Spanish researchers have led, throughout the whole period, in the number of papers published, with 124. Spain was followed by the United States, the United Kingdom, Italy, France, Germany and China, with more than 40 articles in the last 23 years. In terms of funding, 159 administrations have supported some research related to plant phylogeography in MTEs. The European Commission together with the Spanish Ministry of Science and Innovation and the Horizon 2020 Framework Program led the allocation of funds for the implementation of projects. Other official bodies such as the Deutsche Forschungsgemeinschaft, the Austrian Science Fund or the Centre National de la Recherche Scientifique, have also financed this research, although to a lesser. It seems that there is an asymmetry in the dedication of economic efforts toward this research located specifically in the Mediterranean Basin. The general increasing trend in publication rates, which raised particularly rapidly over the past two decades, has been also detected by Fois et al. [54], who suggest that national and international initiatives, laws, conventions, and the establishment of conservation networks could have contributed to such a trend.

After an initial screening, starting in 2003, only 127 papers in which conservation proposals were at least partially based on phylogeographic information were found; despite using the keyword "Mediterranean" in the Scopus search, many of the studies selected are not placed in MTEs. This is due to the fact that the Mediterranean studies usually serve as traditional examples in conservation research; among the 127 papers selected, 78 had, as a focus area, MTE (Table A1 \& Figure 2). The evolution of the number of documents published follows a similar trend to that observed in the general case. The number of research articles from 2014 onward increased exponentially, reaching a maximum number of 19 papers in 2021, 10 papers if we only consider those focused on MTEs (Figure 3).

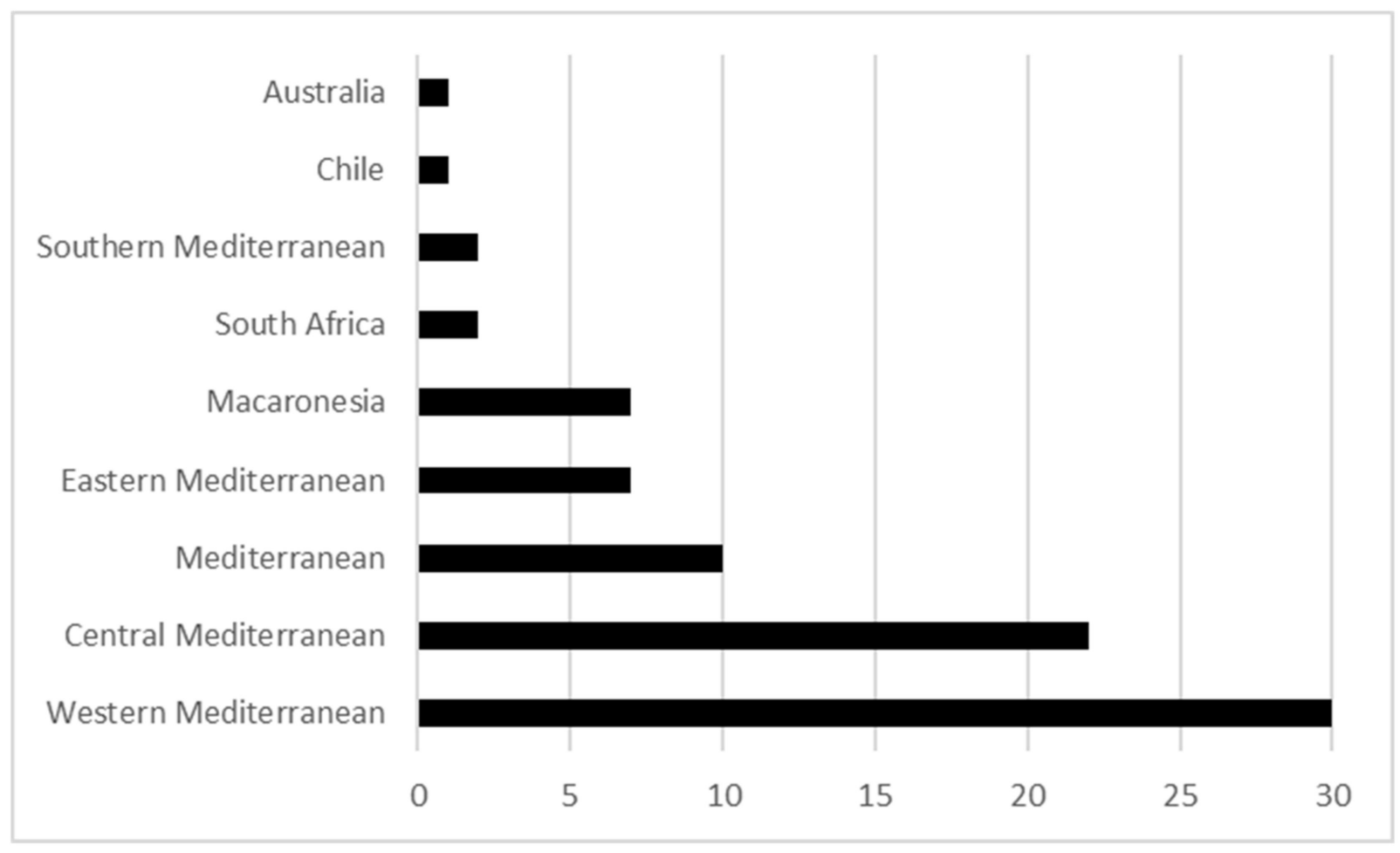

Figure 2. Graph showing the geographic distribution of the 78 documents reviewed within MTEs. 


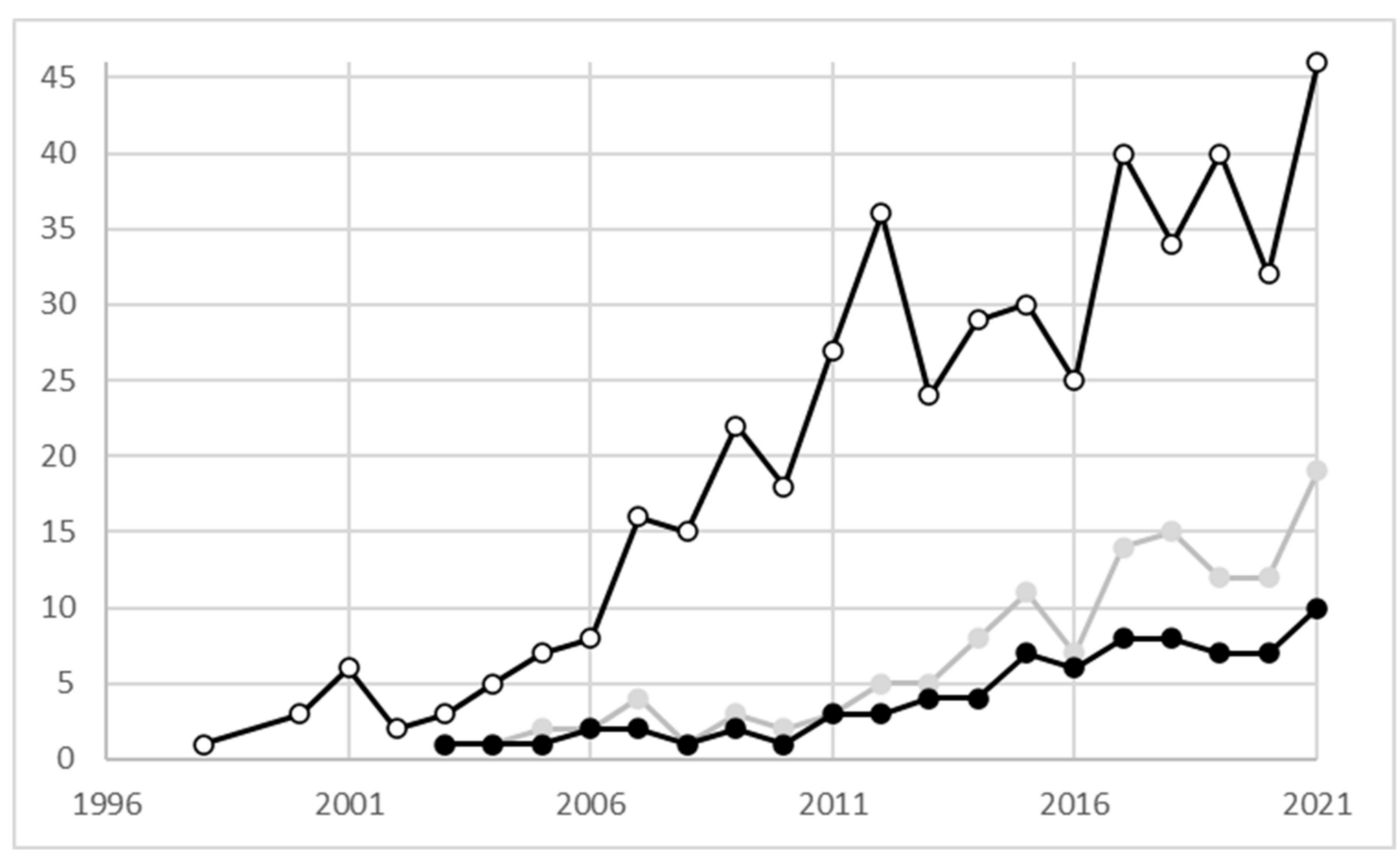

Figure 3. Search results using Scopus; results showing all the documents obtained using the keywords "plant conservation", "phylogeography" and "Mediterranean", and the criterion "AND" that forced the results to include the three keywords (463 documents; black line/white dots); results showing research papers that are plant related in which conservation actions considered the phylogeographic patterns (127 documents; grey line/grey dots); papers with focus on the MTEs (78 documents; Black line/black dots).

The predominance of papers focused on the Mediterranean Basin, specifically in the Northern Mediterranean Basin (see Figure 2), which was also detected by SalmerónSánchez et al., 2021, in the literature review of plant conservation in MTEs. In consequence, it is not strange that, in terms of territory of development, Spain (with 34 documents) and Italy (15) are among the top five (which includes China (19), the United Kingdom (18), Italy (15) and the United States (11) are the countries where most research results have been published on the conservation of flora using phylogeography, although research on this subject has been published by researchers of more than 50 nationalities. More than $99 \%$ of these publications (virtually all of them) correspond to paper format. With five articles or more, impact journals such as PLOS ONE (10), Conservation Genetics (9), Ecology and Evolution (8), Botanical Journal of the Linnean Society (7) and PeerJ (5) were observed, among a total of 55 journals where at least one paper had been published on this topic. The subject areas "Agricultural and Biological Sciences" and "Biochemistry, Genetics and Molecular Biology" represented more than 75\% of the published papers; "Environmental Science" accounted for $14 \%$ of the papers, while other areas such as "Neuroscience", "Medicine", "Earth and Planetary Sciences" or "Immunology and Microbiology" constituted less than $10 \%$ of the total.

The study of the population genetic structure of plant species, in most cases, narrow Mediterranean endemics (36 of the 78 documents have as focus narrow endemic species), is the current trend [22,55,56]. Médail and Baumel [22] argue that comparative phylogeography across several co-occurring taxa could greatly improve proactive conservation actions for threatened endemic plants within biodiversity hotspots. Thus, broader studies by the discipline of phylogeography or comparative phylogeography on the MTEs plants may provide the impetus for more effective and sensible conservation measures to protect and improve the state of this Biome. 


\section{The Convergence of Phylogeography and Conservation}

Although commonly assumed as highly needed and given that genetic diversity and knowledge of population structure of the species helps to manage and restore endangered species [57], genetic studies are unfortunately rarely included into the conservation programs $[22,58,59]$. This is of essential importance, as plant genetic diversity is spatially structured at different scales [60,61], and not including these genetic patterns may result in failing proposals. Multidisciplinary approaches should consider molecular data together with ecological and environmental data to assure proper biological conservation [62]. Geographic patterns of genetic diversity and rarity also play an important role regarding management schemes, as the resources are often limited, the effort needs to be focused on specific populations or areas needing recovery [21,63]. It is also important to consider that geographical shared patterns are extremely useful to design conservation areas over species level, as they represent the historic signal of event common to multiple species as refugial areas, general geographic barriers and other evolutionary processes [64,65].

Regarding translocations (e.g., reinforcement of genetic impoverished populations and reintroduction of extinct populations), the absence of phylogeographic information results in the blurring of the present genetic patterns and limits the possibility of understanding the evolutionary processes of species [66]; this also obscures the response that species had to past environmental changes, and given the future climate change scenario, unplanned reinforcement, rehabilitation or restoration of populations could limit the adaptive capacity of the species $[22,67,68]$. Genetic data should also be the decision-making basis in the cases of assisted migration [69], as the selection of seeds from genetically similar areas reduces the risk of outbreeding depression [70].

\subsection{Phylogeography and In Situ Conservation}

Despite the controversial issues of the species concept ([71,72], among many others) it is commonly assumed in conservation that we should protect species [73]. However, many international organizations inherently accept that the conservation units should also focus on the adaptative potential of the species as it represents evidence for speciation $[74,75]$. Below the species level, the genetic diversity pattern provides fundamental information on biological and evolutionary processes that might affect the adaptation and the present environmental response of plant species. These levels of genetic variability are mainly due to natural selection, migration, population depletion, gene flow, inbreeding and to biological traits such as pollination, etc. [76]. In general, to consider only phylogenetic diversity as a successful proxy for evolutionary potential and adaptation does not work $[77,78]$. To optimize management efforts, the evolutionary potential of the species should be taken into account [79].

In consequence, in order to improve conservation efforts, it is essential to include phylogeographic studies that analyze the spatial partitioning of genetic diversity, the genetic relationship among individuals, and the levels of gene flow to complement reproductive and biogeographical data of many threatened plants [21].

As a result, some conservation estimators have been proposed to link the phylogeographic signal and the conservation efforts. The first estimator proposed in order to meet both requirements is the Evolutionary Significant Unit (ESU) [19]. ESUs were developed as a below-species level approach considering that economic and human resources are limited [80] and full species conservation is unrealistic. ESUs establish populations or group of populations as conservation units considering significant adaptive variation based on concordance between sets of data derived by different techniques (life history information, morphometric, range and distribution data, and genetic data [81]. The original concept has been redefined by some authors, in some cases giving more importance to the molecular data in order to establish the conservation units [20,82-85], while some other authors have proposed both molecular data and ecological traits [86-89]. All these definitions suggest that a static definition of the ESUs concept is impossible [83] since it varies depending on the characteristics of the species considered. Moreover, the ESUs concept is limited by 
the lack of phylogenetic information, making it difficult to structure the populations at a biogeographical level [82].

To bypass the phylogenetic constraints of the ESUs concept, Mortiz [20] proposed the Management Unit (MU); this proposal was focused on present population structure, while the historical factors underlying the actual diversity and structure were partially overlooked; it is obvious that this concept partially betrays the idea of conservation based on phylogeography, only focusing on local adaptations with uncertain evolutionary potential.

Trying to give importance to the phylogeography considerations, Doadrio et al. [90] introduced the Operational Conservation Unit concept (OCUs), which is defined as a continuous area limited by geographical boundaries and inhabited by one or more populations sharing the same genetic pattern. Despite the simplicity of the proposal, this estimator has been scarcely used and always with fauna [91-93].

Considering the factors that could have influenced the evolutionary history of the different lineages of the species [94], Pérez-Collazos et al. [21] proposed the Relevant Genetic Units for Conservation (RGUCs). This approach is based on the belief that rare alleles are essential for species or taxa conservation, as they hold the evolutionary and/or adaptative potential of the species [21,95-97]. The use of both common and rare alleles the RGUCs approach allows one to estimate the total number of populations needed to preserve the full genetic variability of the species and to select which populations should be chosen to meet the conservation goals.

Finally, as an alternative to the ESU concept and based on variation in ecology, local adaptation and phylogeographic history, the Committee on the Status of Endangered Wildlife in Canada (COSEWIC) proposed the Designatable Unit (DU) [98]. This approach was intended to identify distinct populations from endangered species in order to make the conservation effective, especially when a strict taxonomic approach is not possible and there are no taxonomic designations below species level [98].

Despite the available proposals, in order to establish phylogeographical units with a conservation purpose, we detected few articles that use one of these proposed methodologies (Table A1). However, it is common to use the phylogeographic signal to make direct proposals regarding the genetic structure; we also detected that some phylogenetic and/or phylogeographic studies focused on endemic or endangered species mentioned the importance of the phylogeographic patterns in order to establish conservation measures but did not address the problem ([99-106], among others).

\subsection{Phylogeography and Ex Situ Conservation}

Although in situ conservation proposals are the most appropriate for the protection of plant species [107], ex situ conservation techniques are essential conservation tools, and their relevance has gained international recognition in recent years [108], especially for some taxa in which range of distribution or number of populations exceeds the resources available when making conservation proposals [21]. Moreover, genetic diversity is considered one of the most important parts when it comes to plant restoration [109-111]. Several reviews have been written about how to make seed collections and the importance of considering the genetic information in restoration proposals [112-115]. Despite this, only few of the proposed translocations made were based on genetic data [110], and this is causing most of the reintroductions to end up being not successful [116].

As for the in situ conservation proposals, the knowledge of genetic diversity patterns of the species in their natural populations is an essential requisite to designing a successful sampling strategy to create ex situ conservation proposals as seed banks $[107,117,118]$; this is because the genetic diversity is supposed to match the biological attributes of species. Given this and the reduction of the adaptive ability of the populations to a rapid change environment scenario in species with limited gene pool ([119], among others), the gathering of all the genetic diversity of the species should be the goal in order to create viable and useful seed banks and other ex situ conservation strategies [117]. As for in situ conservation, 
when this is not possible for economic or other reasons, the most representative populations should be chosen to develop proper conservation guidelines $[19,120]$.

Some authors have proposed guidelines in order to create seed banks following the genetic patterns of the species $[113,115,121]$. Moreover, and similar to the ESUs, some authors have expressed the necessity of a phylogeographic approach in order to identify the areas in which historical and contemporary gene flow occurs [122], these "seed zones" [115] would be areas within the plant material that can be translocated without negative effects.

Molecular markers and habitat differences should be used in combination to delineate phylogeographic groups, which provide the basis for designing "seed zones" (e.g., [115,122-125]). Several examples can be found about the use of molecular markers to delineate the seed zones $[20,120,126,127]$.

Despite the multiple implications that can affect the viability of a translocation [128] and given that the real reasons of failure are unknown in many cases [129], at least two main concerns need to be addressed when dealing with them, outbreeding and inbreeding depression, both of which must be considered, as they may influence the survival of the species [130,131]. The establishment of phylogeographical "seed areas" can help to avoid outbreeding depression. These "seed areas" would impede the movement of plant material among ecologically different areas, affecting the survival of the population, given the reduction of the adaptative potential [131]. Regarding inbreeding depression, the lack of knowledge when translocating plant material and the low number of individuals usually translocated result in the impoverishment of genetic diversity [132,133], with the resulting populations unable to adapt to the environmental changes $[128,134,135]$.

The last consideration involved gathering seeds, and taking into account that sometimes the number of available seeds in the populations is extremely scarce, some authors have proposed the calculations of the optimal proportions of the populations in order to create optimal genetic diversity seed banks $[126,127]$. This would ensure the gathering of all the genetic diversity of the seed areas, and at the same time, it would respect the natural populations in order not to generate a negative effect [136].

\section{Future Perspectives}

Taking into account how highly relevant phylogeography has become an establishment of priorities for conservation, systematics and conservation units must be linked to the need to clearly delineate evolutionary entities, which must be those that will be subject to conservation [22]. To achieve this, the integration of genetic (or genomic), biological and ecological data is also fundamental. Furthermore, it is important to reveal the cryptic evolutionary legacy that underlies in some species, as well as the signs of adaptive evolution that may be operating in certain changes in ecosystems.

Over the years, phylogeography has evolved with the aid of a range of multilocus markers such as AFLPs, microsatellites, or SNPs [137] (for more details of the methodologies employed, see Figure 4). The scarce studies published during the earlier 2000s used allozymes and RAPD as molecular markers to establish phylogeographic structures of populations and levels of genetic diversity $[67,138]$. These methodologies showed certain limitations (RAPD suffered from a certain lack of reproducibility due to mismatch annealing, meanwhile allozymes showed low variability; see [139]). Throughout time, the number of publications increased exponentially, incorporating into genome scanning techniques, others that showed greater reliability, such as that which generated dominant AFLPs [21,140], or the codominant SSR [141,142]. The robustness and quality of the information obtained from these techniques remain effective, taking into account the number of studies that continues to be carried out with these type of molecular markers [126,143]. The information provided by these techniques has been complemented by that of other types of molecular markers, such as nuclear and plastid sequences $[79,144]$ (the latter is widely used in plants; see Figure 4). Although these techniques detect low values of intrapopulational genetic diversity, plastid and nrDNA are widely used for determining phylogeographical patterns [145-148]. Furthermore, nrDNA allows for the detection of recent hybridization events [149]. 


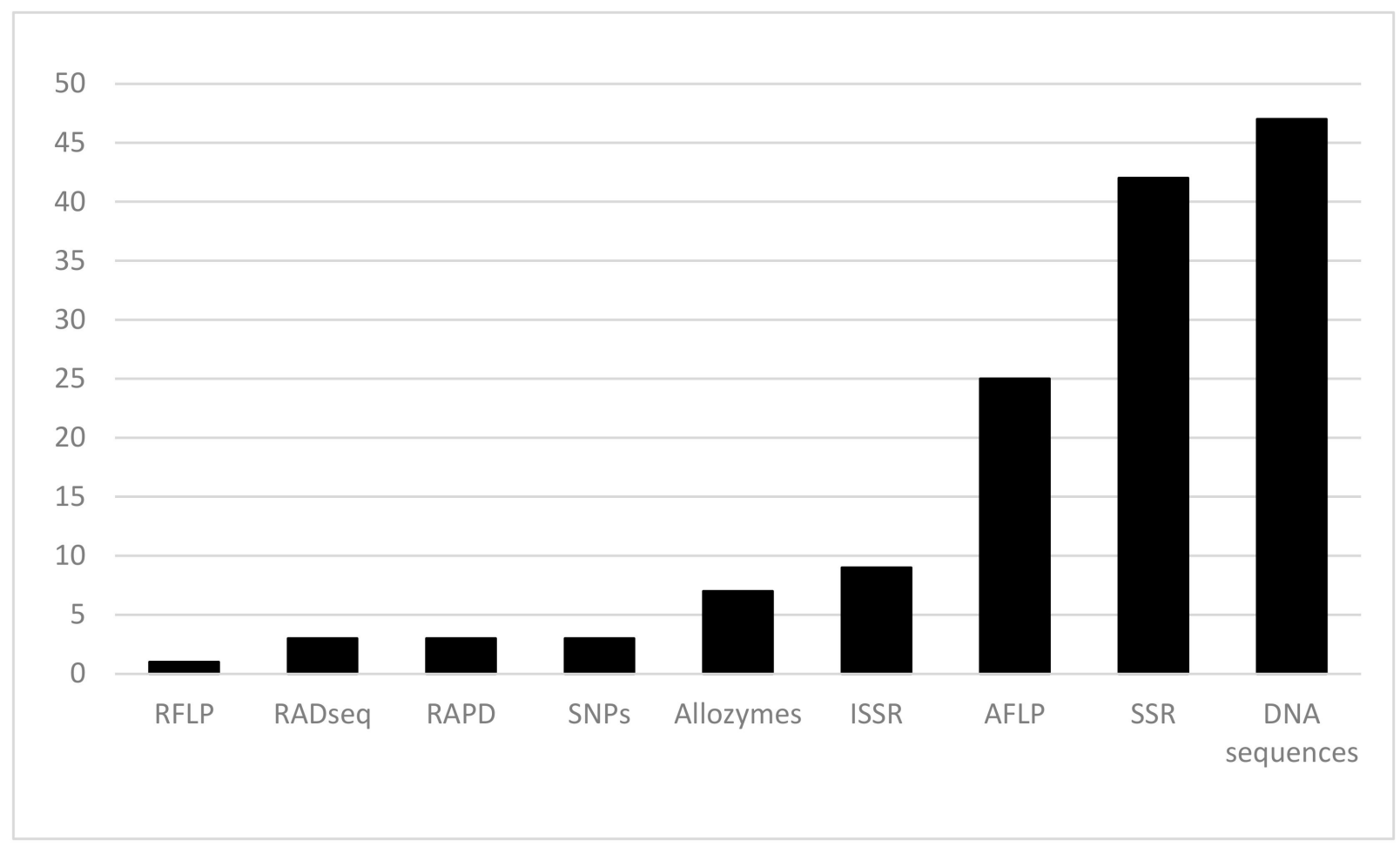

Figure 4. Graph showing the number of times that the different genetic methodologies have been used in order to propose species conservation measures regarding the phylogeographic pattern.

In recent years, and as a result, technological development novel HTS-based techniques (high throughput sequencing) have increased their presence. According to NietoFeliner [137], in the field of phylogeography, it points toward advances in the availability of high throughput sequencing techniques, even for non-model organisms [150]. This does not mean that the use of neutral molecular markers such as AFLP, with which a reducedrepresentation-based genome-wide marker-discovery strategy is achieved and is not still good for phylogeographic studies. A comparative work between AFLP (a non-HTS based technique) and restriction site-associated DNA sequencing (RADseq; an HTS-based technique) [151] demonstrated similarities of results from the two techniques, which validate the use of these techniques in the delimitation of evolutionary entities.

With this in mind, the advent of genomic sequencing allows conservation biologists to have a series of new tools that will help them to reach a better resolution, and not only in the analysis of global genetic diversity, but also in the study of signals of adaptive evolution, mutations, and inbreeding [152].

Due to the high resolution of these new tools, it is possible to enable a deeper scrutiny of the levels of genetic diversity present in species, even more than in those where it has not been possible to appreciate any differentiation. According to Coates et al. [153], genome scale analyses reveal highly divergent genetic populations within named species (cryptic species [154-156]), or they facilitate the reveal of genetic exchanges (introgression) among species during and after speciation, which can even drive new adaptive radiations [157-159]. These methodologies can be useful in taxonomy, in the resolution of species boundaries that had not previously been possible to establish, e.g., Lomatium packardiae Cronquist/ L. anomalum M.E. Jones ex J.M. Coult. \& Rose clade of the L. triternatum (Pursh) J.M. Coult. \& Rose (Apiaceae) complex, with the aid of the Angiosperms353 probe set [160], or in the detection of genetic structures where with other markers it has not been possible, as in the case of the study of the genetic structure of the endangered salt marsh plant Chloropyron maritimum (Nutt. Ex Benth.) A. Heller [161]. Due to them, it has also been possible to describe new species (e.g., Ceanothus L. genus in California) [162] or to modify the conservation status [55], as in the case of Cynara baetica (Spreng.) Pau subspecies. 
As mentioned above, these new tools are also useful when studying selection, adaptation and functional diversity in threatened species. Now, it is possible to analyze genetic diversity and patterns of local adaptation with the aid of functional variants. This would allow for the identification of possible populations from which to translocate and restore intensifying local adaptation [152]. In such studies, the use of population genetic data, which have traditionally been used for the establishment of priorities for conservation, need the integration of other disciplines.

A good example is the study in Araucaria araucana (Molina) K. Koch [163]. Here, the authors recommend different populations as priorities for conservation on the basis of the presence of loci AFLP with low frequencies that are correlated with different environmental variables, which can be important to confront future changes in climatic conditions. Another example is the potential selection in response to sea surface temperatures in seaweed Phyllospora comosa (Labillardière) C. Agardh [164]. An added study case refers to Banksia hookeriana Meisn [165]; due to the characterization of its leaf transcriptome, it has been possible to identify genes implied in the adaptation to dry Mediterranean type. These genes could be used in the genotype and genetic diversity studies of Banksia genus. Another study that continues in the same direction [166] has allowed researchers to detect, through genomic sequencing, local adaptation to aridity in the Eucalyptus genus. There are some examples of translocation that have been carried out following the information provided from these techniques, for example, the study of Eucalyptus melliodora A. Cunn. ex Schauer [167]. The authors combined genomic data with environmental variables and climate predictions to identify sites for assisted migration as well as potential source populations. The practice of "genetic rescue" was also facilitated. Pickup et al. [168] increased levels of heterosis with the aid of experimental crosses between populations of Rutidosis leptorrhynchoides F. Muell.

Future directions that plant conservationists will move toward should include epigenetics. Today, different HTS cost-efficient approaches to detect epigenetic variation are available (BS-seq approaches: DyMe-Seq, BisPCR, RRBS ... ). From the point of view of Rey et al. [169], epigenetic conservation will provide the possibility of refining ESUs, considering the capacity of organisms to rapidly cope with environmental changes and improve conservation.

The use of population genetic data, which have traditionally been used for the establishment of priorities for conservation, can be reinforced with the integration of other disciplines. Thus, multidisciplinary approaches are becoming more relevant. For example, in CFP, Baldwin's review [170] highlights studies on a regional scale, spatial patterns of Californian species' richness, phylogenetic diversity, and phylogenetic endemism. In addition, in CFP or Kling et al. [171], novel analyses of the different facets of phylodiversity allow for the establishment of conservation priorities.

During the last years, the establishment of management plans, along with other methods, are being included as Environmental (or Ecological) Niche Modelling (ENM), as these models can provide insights into the ecology of species [172]. ENM uses target species distribution data (abundance or occurrences at known locations) together with environmental data to understand and predict the relative probability of presence in other locations that have not been studied. According to Elith and Leathwick [172], ENM allows for the prediction of new locations at the present time frame or for future or past climate scenarios. This method, applied to species conservation, has been successfully used in the detection of new populations [173-176]. Moreover, it can be useful in territories where the orography has recently changed (e.g., eastern Asia), as they would help to know the historical distribution of species [177]. ENM, in combination with genetic techniques, allows one to illuminate how the species level versus intraspecific ESUs may differ in their habitat preferences (e.g., [178-180]). In addition, they allow one to infer climate change-associated correlations between genetic structure distribution shifts [181-183].

Among the most recent works that integrate niche modeling with genetic analysis is the study by Han et al. [184] on the species Quercus gilva Blume. This study, due to a combination of genetic and ENM data, suggests the designation of a single MU specifically 
on Jeju island, given its great genetic differentiation and its possible independent origin in relation to Japanese localities. In the same direction, the study of Nualart et al. [185] stated that the combination of genetic, ecological, and niche modeling data, allowed one to differentiate between two taxa of the genus Petrocoptis A. Braun ex Endl., P. montsicciana O. Bolòs \& Rivas Mart and P. pardoi Pau, and it recommended that they must be regarded as separated management units (MU). In another study, Nygaard et al. [186] clearly shows that Carex jemtlandica (Palmgr.) Palmgr. and C. lepidocarpa Tausch represent separately evolving entities that should qualify recognition as evolutionary significant units (ESU). This conclusion was reached after corroborating morphological data with genetic data and was supported by the ecological niche modeling data, which suggest that they occupy different environmental niches.

\section{Conclusions}

This review shows a systematic overhaul of the literature on the state of the art in phylogeography applied to the conservation of the evolutionary potential of plant species, especially in Mediterranean-type ecosystems, which are home to a significant number of endemic, rare or threatened taxa. In addition, we reviewed the future directions of phylogeography-based conservation approaches and on how particular methodologies and conceptual bases applied to species conservation are being developed and implemented. In general, despite the rapid growth, a limited use of phylogeography in the development of conservation programs is still obvious. The number of papers that propose conservational measures based on phylogeographical data is still scarce, especially regarding to concrete methodological proposal (e.g., RGUCs, ESUs, etc.). Moreover, it is important to highlight that despite its great potential, the use of phylogeographic studies (and genetic studies in general) for the establishment of conservation priorities still does not have sufficient support from the administrations. According to our own experience, phylogeographic criteria are useful in the case of plants with disjunct distribution, which is frequent in high mountain and insular species and those typical of special substrates such as ultramafic, gypsum, dolomite and others. Finally, despite that the current research trends to develop new DNA techniques in order to propose conservation and management measures, the usefulness of pre-HTS molecular markers may be valid for the establishment of these conservation priorities; this genetic information, which is already available, could and should therefore be used.

Author Contributions: Conceptualization, J.P. and J.F.M.; Methodology, J.P., J.B.-P., A.J.M.-F. and E.S.-S.; Formal Analysis, J.B.-P., A.J.M.-F. and E.S.-S.; Writing-Original Draft Preparation, all authors; Writing-Review and Editing, all authors; Visualization, J.B.-P., A.J.M.-F. and E.S.-S. All authors have read and agreed to the published version of the manuscript.

Funding: This research received no external funding.

Institutional Review Board Statement: Not applicable.

Informed Consent Statement: Not applicable.

Conflicts of Interest: The authors declare no conflict of interest. 


\section{Appendix A}

Table A1. Research articles obtained after the Scopus search using the keywords "plant conservation", "phylogeography" and "Mediterranean", and the criterion "AND" that forced the results to include the three keywords and after the screening to only consider plant-related research articles in which conservation proposals were made considering the phylogeographic patterns.

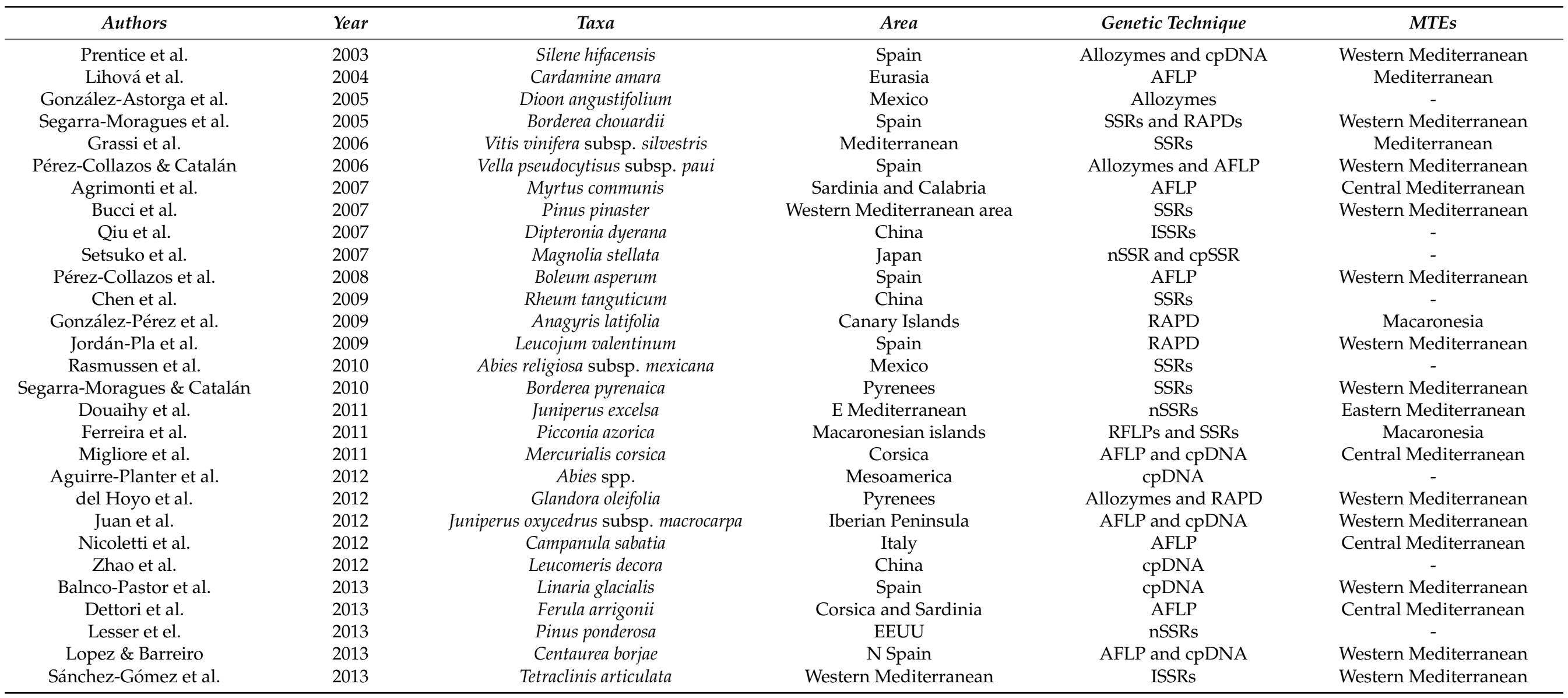


Table A1. Cont.

\begin{tabular}{|c|c|c|c|c|c|}
\hline Authors & Year & Taxa & Area & Genetic Technique & MTEs \\
\hline Carcía-Castaño et al. & 2014 & Chamaerops humilis & $\begin{array}{l}\text { Central and Western } \\
\text { Mediterranean }\end{array}$ & & $\begin{array}{l}\text { Central and Western } \\
\text { Mediterranean }\end{array}$ \\
\hline Christe et al. & 2014 & Zelkova spp. & Sicily, Crete and Transcaucasia & cpDNA & $\begin{array}{l}\text { Central and Eastern } \\
\text { Mediterranean }\end{array}$ \\
\hline Fernández-Mazuecos et al. & 2014 & Naufraga balearica & Majorca & AFLP and cpDNA & Western Mediterranean \\
\hline Liu et al. & 2014 & Acer mono var. mono & China & nSSRs & - \\
\hline Poudel et al. & 2014 & Taxus spp. & Himalaya & cpDNA and SSRs & - \\
\hline Poudel et al. & 2014 & Taxus contorta & Pakistan & cpDNA and SSRs & - \\
\hline Rumeu et al. & 2014 & Juniperus cedrus & Canary Islands & AFLP and cpDNA & Macaronesia \\
\hline Sánchez et al. & 2014 & Pinus caribaea var. bahamensis & Caribe & cpDNA and nDNA & - \\
\hline Bjedov et al. & 2015 & Vaccinum spp. & E Europe & RAPD & Eastern Mediterranean \\
\hline Cánovas et al. & 2015 & Viola cazorlensis & Spain & ISSRs & Western Mediterranean \\
\hline Coates et al. & 2015 & Banksia brownii & Canada & nSSRs & - \\
\hline Deacon et al. & 2015 & Quercus oleoides & Costa Rica & SSRs & - \\
\hline Gentili et al. & 2015 & Ribes spp. & Sardinia & ISSRs & Central Mediterranean \\
\hline Giovino et al. & 2015 & Pacratium maritimum & Europe & cpDNA & Mediterranean \\
\hline Huerta-Ramos et al. & 2015 & Ipomoea sagittata & Mexico & cpADN and ITS & - \\
\hline Larridon et al. & 2015 & Copiapoa spp. & S America & cpDNA & Chile \\
\hline Vitales et al. & 2015 & Cheirolophus uliginosus & Iberian Peninsula & AFLP, cpDNA and ITS & Western Mediterranean \\
\hline Kajtoch et al. & 2016 & 18 taxa & E Europe & - & Eastern Mediterranean \\
\hline Martin et al. & 2016 & Silene nutans & Europe & SNPs and nSSRs & Mediterranean \\
\hline Martín-Hernanz et al. & 2016 & Coronopus navasii & Spain & cpDNA and ITS & Western Mediterranean \\
\hline Peñas et al. & 2016 & Astragalus edulis & W Mediterranean & AFLP and cpDNA & Western Mediterranean \\
\hline Plenk et al. & 2016 & Gentianella bohemica & C Europe & AFLP & Central Mediterranean \\
\hline Rešetnik et al. & 2016 & Salvia officinalis & Eastern Europe & SSRs & Eastern Mediterranean \\
\hline Wen et al. & 2016 & Salsola junatovii & China & cpDNA and ITS & - \\
\hline Bao et al. & 2017 & Prunus mira & Europe & SSRs & Mediterranean \\
\hline Belletti et al. & 2017 & Abies alba & Italy & SSRs & Central Mediterranean \\
\hline Bouchard et al. & 2017 & Dryopteris fragrans & North America & ISSRs & - \\
\hline Duwe et al. & 2017 & Arnica montana & Europe & nSSR & Mediterranean \\
\hline Frey et al. & 2017 & Trapa natans & C Europe & AFLP and ITS & - \\
\hline Guzmán et al. & 2017 & Galvezia leucantha & Galapagos Islands & cpDNA and ITS & - \\
\hline
\end{tabular}


Table A1. Cont.

\begin{tabular}{|c|c|c|c|c|c|}
\hline Authors & Year & Taxa & Area & Genetic Technique & MTEs \\
\hline Hrivnák et al. & 2017 & Abies taxa & E Mediterranean & nSSRs & Eastern Mediterranean \\
\hline Hu et al. & 2017 & Juglans hopeiensis & China & cpDNA and nDNA & - \\
\hline Jiménez-Mejías etal. & 2017 & Castrilanthemum debeauxii & Spain & AFLP and cpDNA & Western Mediterranean \\
\hline Kwak et al. & 2017 & Abies koreana & Korea & SSRs & - \\
\hline Lázaro-Nogal et al. & 2017 & Cneorum tricoccon & Western Mediterranean & SSRs & Western Mediterranean \\
\hline Pouget et al. & 2017 & Acis nicaeensis & French-Italian Riviera & cpDNA & Central Mediterranean \\
\hline Sanz et al. & 2017 & Artemisia umbelliformis & W Europe & AFLP & Western Mediterranean \\
\hline Wei et al. & 2017 & Camellia flavida & China & nDNA and cpDNA & - \\
\hline Chung et al. & 2018 & Orchids & Korea & Allozymes & - \\
\hline Chung et al. & 2018 & Lilium cernuum & Nort east Asia & Allozymes & - \\
\hline De Luca et al. & 2018 & Phaseolus vulgaris & Italy & nSSRs & Central Mediterranean \\
\hline Gentili et al. & 2018 & Leucojum aestivum & N Italy & AFLP & Central Mediterranean \\
\hline Gentili et al. & 2018 & Ribes sardoum & Cerdeña & SSRs & Central Mediterranean \\
\hline Gutiérrez-Ortega et al. & 2018 & Dioon sonorense & west coast Mexico & ISSRs & - \\
\hline Mairal et al. & 2018 & $\begin{array}{l}\text { Canarina eminii and Canarina } \\
\text { canariensis }\end{array}$ & Afro-Macaronesian forests & nSSR & $\begin{array}{l}\text { Western Mediterranean } \\
\quad \& \text { Macaronesia }\end{array}$ \\
\hline Martín-Hernanz et al. & 2018 & Helianthemum genus & Spain & SSRs & Western Mediterranean \\
\hline Menezes et al. & 2018 & Campanulaceae & Macaronesian islands & cpDNA and ITS & Macaronesia \\
\hline Tamaki et al. & 2018 & Pseudotsuga japonica & Japan & SSRs & - \\
\hline Van Rossum et al. & 2018 & Silene nutans & Europe & cpDNA & Mediterranean \\
\hline Wang et al. & 2018 & Bretschneidera sinensis & Asia & cpDNA & - \\
\hline Yan et al. & 2018 & Quercus section Cyclobalanopsis & East Asia & cpDNA & - \\
\hline Bezemer et al. & 2019 & Eucalyptus caesia & south-west Australia & SSRs & Australia \\
\hline Gargiulo et al. & 2019 & Asperula crassifolia & Western Mediterranean & cpDNA and SSRs & Western Mediterranean \\
\hline Grdiša et al. & 2019 & Sideritis scardica & southern Balkan Peninsula & AFLP & Central Mediterranean \\
\hline Kusuma et al. & 2019 & Vatica bantamensis & Indonesia & ISSRs & - \\
\hline Louati et al. & 2019 & Argania spinosa & Tunisia & ISSRs & Southern Mediterranean \\
\hline Ramírez-Rodríguez et al. & 2019 & Delphinium fissum subsp. Sordidum & Spain & cpDNA & Western Mediterranean \\
\hline Romdhane et al. & 2019 & Pennisetum glaucum & Tunisia & nSSRs & Southern Mediterranean \\
\hline Rutherford et al. & 2019 & Eucalyptus tetrapleura & New South Wales & SNPs & - \\
\hline Stefenon et al. & 2019 & Araucaria angustifolia & Brazil & cpDNA & - \\
\hline Walas et al. & 2019 & Aesculus hippocastanum & Greece & nSSRs & Central Mediterranean \\
\hline
\end{tabular}


Table A1. Cont.

\begin{tabular}{|c|c|c|c|c|c|}
\hline Authors & Year & Taxa & Area & Genetic Technique & MTEs \\
\hline Xu et al. & 2019 & Paeonia qiui, P. jishanensis, and P. rockii & China & nSSRs and cpDNA & - \\
\hline Zhao et al. & 2019 & Tugarinovia mongolica & Asia & cpDNĀ & - \\
\hline Amaral Fraga et al. & 2020 & Coleocephalocereus purpureus & Eastern Brazil & SSRs & - \\
\hline Durán et al. & 2020 & Dracaena spp. & Macaronesian islands & cpDNA & Macaronesia \\
\hline Fassou et al. & 2020 & Helleborus odorus subsp. cyclophyllus & Balkan Peninsula & ISSRs & Central Mediterranean \\
\hline Galuszynski \& Potts & 2020 & $-\quad 1<0$ & southern Cape of South Africa & - & South Africa \\
\hline Kropf et al. & 2020 & Adonis vernalis & Central Europe & AFLP and cpDNA & - \\
\hline Kvesić et al. & 2020 & Acer campestre & Bosnia and Herzegovina & SSRs & Central Mediterranean \\
\hline Liber et al. & 2020 & Degenia velebitica & north-western Dinaric Alps & AFLP & - \\
\hline López-Alvarado et al. & 2020 & Centaurea spp. & Central Mediterranean & & Central Mediterranean \\
\hline Meloni et al. & 2020 & Ruta corsica and $R$. lamarmorae & Corsica and Sardinia & SSRs & Central Mediterranean \\
\hline Sękiewicz et al. & 2020 & Cupressus atlantica & High Atlas & SSRs & Western Mediterranean \\
\hline Shahzad et al. & 2020 & Dipteronia sinensis & Qinling Mountains & plastid genome and SNPs & - \\
\hline Urquía et al. & 2020 & Psidium galapageium & Galapagos Islands & SSRs & - \\
\hline Alipour et al. & 2021 & Populus caspica & Hyrcanian forests & SSRs & - \\
\hline Bobo-Pinilla et al. & 2021 & Jacobaea auricula & Spain & AFLP and cpDNA & Western Mediterranean \\
\hline Bobo-Pinilla et al. & 2021 & Astragalus edulis & western Europe & AFLP and cpDNA & Western Mediterranean \\
\hline Casazza et al. & 2021 & Lilium pomponium & Maritime and Ligurian Alps & AFLP & - \\
\hline Galuszynski & 2021 & Cyclopia genus & southern Cape of South Africa & cpDNA & South Africa \\
\hline Garcia-Jacas et al. & 2021 & Seseli farrenyi & W Mediterranean basin & SSRs & Western Mediterranean \\
\hline Hellwig et al. & 2021 & Pisum fulvum & $\begin{array}{c}\text { Israel and the Palestinian } \\
\text { territories }\end{array}$ & RAD & Eastern Mediterranean \\
\hline Jones et al. & 2021 & Astragalus spp. & Utah, USA & RAD & - \\
\hline Kim et al. & 2021 & Fraxinus chiisanensis & Korea & cpDNA and ITS & - \\
\hline Kougioumoutzis et al. & 2021 & 7043 native plant taxa & Greece & Multiple DNA markers & Central Mediterranean \\
\hline Lin et al. & 2021 & Pinus subsect. strobus & China & cpDNA and mtDNA & - \\
\hline Lin et al. & 2021 & Myripnois dioica & Northern China & RAD & - \\
\hline Medail et al. & 2021 & Acis nicaeensis & French-Italian Riviera & cpDNA & Central Mediterranean \\
\hline Roxo et al. & 2021 & subtribe Daucinae & Macaronesian islands & Genome size & Macaronesia \\
\hline Vaculná et al. & 2021 & Adenophora liliifolia & Central Europe & AFLP and cpDNA & - \\
\hline Yun \& Kim & 2021 & Saussurea polylepis & Korea & SSRs & - \\
\hline Žerdoner Čalasan et al. & 2021 & Sisymbrium genus & Old-World & cpDNA and ITS & Mediterranean \\
\hline
\end{tabular}




\section{References}

1. Avise, J.C.; Arnold, J.; Ball, R.M.; Bermingham, E.; Lamb, T.; Neigel, J.E.; Reeb, C.A.; Saunders, N.C. Intraspecific Phylogeography: The Mitochondrial DNA Bridge Between Population Genetics and Systematics. Annu. Rev. Ecol. Syst. 1987, 18, 489-522. [CrossRef]

2. Avise, J.C. Phylogeography: The History and Formation of Species; Harvard University Press: Cambridge, MA, USA, 2000; ISBN 9780674666382.

3. Riddle, B.R.; Hafner, D.J. Phylogeography in Historical Biogeography: Investigating the Biogeographic Histories of Populations, Species, and Young Biotas. In Biogeography in a Changing World; Ebach, M., Tangney, R., Eds.; CRC Press: Boca Raton, FL, USA, 2006.

4. Webb, C.O.; Ackerly, D.D.; McPeek, M.A.; Donoghue, M.J. Phylogenies and Community Ecology. Annu. Rev. Ecol. Syst. 2002, 33, 475-505. [CrossRef]

5. Hickerson, M.J.; Carstens, B.C.; Cavender-Bares, J.; Crandall, K.A.; Graham, C.H.; Johnson, J.B.; Rissler, L.; Victoriano, P.F.; Yoder, A.D. Phylogeography's past, present, and future: 10 years after Avise, 2000. Mol. Phylogenet. Evol. 2010, 54, 291-301. [CrossRef] [PubMed]

6. Hewitt, G. The genetic legacy of the Quaternary ice ages. Nature 2000, 405, 907-913. [CrossRef]

7. Petit, R.J.; Hampe, A.; Cheddadi, R. Climate changes and tree phylogeography in the Mediterranean. Taxon 2005, 54, 877-885. [CrossRef]

8. Sanmartín, I. Historical Biogeography: Evolution in Time and Space. Evol. Educ. Outreach 2012, 5, 555-568. [CrossRef]

9. Buisson, E.; De Almeida, T.; Durbecq, A.; Arruda, A.J.; Vidaller, C.; Alignan, J.; Toma, T.S.P.; Hess, M.C.M.; Pavon, D.; Isselin-Nondedeu, F.; et al. Key issues in Northwestern Mediterranean dry grassland restoration. Restor. Ecol. 2021, 29. [CrossRef]

10. Haddad, N.M.; Brudvig, L.A.; Clobert, J.; Davies, K.F.; Gonzalez, A.; Holt, R.D.; Lovejoy, T.E.; Sexton, J.O.; Austin, M.P.; Collins, C.D.; et al. Habitat fragmentation and its lasting impact on Earth's ecosystems. Sci. Adv. 2015, 1. [CrossRef]

11. Forest, F.; Grenyer, R.; Rouget, M.; Davies, T.J.; Cowling, R.M.; Faith, D.P.; Balmford, A.; Manning, J.C.; Procheş, S.; van der Bank, M.; et al. Preserving the evolutionary potential of floras in biodiversity hotspots. Nature 2007, 445, 757-760. [CrossRef]

12. Médail, F. Plant Biogeography and Vegetation Patterns of the Mediterranean Islands. Bot. Rev. 2021. [CrossRef]

13. Avise, J.C. Phylogeography: Retrospect and prospect. J. Biogeogr. 2009, 36, 3-15. [CrossRef]

14. Kidd, D.M.; Ritchie, M.G. Phylogeographic information systems: Putting the geography into phylogeography. J. Biogeogr. 2006, 33, 1851-1865. [CrossRef]

15. Laikre, L.; Hoban, S.; Bruford, M.W.; Segelbacher, G.; Allendorf, F.W.; Gajardo, G.; Rodríguez, A.G.; Hedrick, P.W.; Heuertz, M.; Hohenlohe, P.A.; et al. Post-2020 goals overlook genetic diversity. Science 2020, 367, 1083-1085. [CrossRef] [PubMed]

16. Frankham, R.; Ballou, J.D.; Briscoe, D.A.; McInnes, K.H. A Primer of Conservation Genetics; Cambridge University Press: Cambridge, UK, 2004; ISBN 9780521831109.

17. Holderegger, R.; Balkenhol, N.; Bolliger, J.; Engler, J.O.; Gugerli, F.; Hochkirch, A.; Nowak, C.; Segelbacher, G.; Widmer, A.; Zachos, F.E. Conservation genetics: Linking science with practice. Mol. Ecol. 2019, 28, 3848-3856. [CrossRef]

18. Habel, J.C.; Assmann, T.; Schmitt, T.; Avise, J.C. Relict Species: From Past to Future. In Relict Species; Springer: Berlin/Heidelberg, Germany, 2010; pp. 1-5.

19. Ryder, O.A. Species conservation and systematics: The dilemma of subspecies. Trends Ecol. Evol. 1986, 1, 9-10. [CrossRef]

20. Moritz, C. Defining “Evolutionarily Significant Units”. Tree Genet. Genomes 1994, 9, 373-375.

21. Pérez-Collazos, E.; Segarra-Moragues, J.G.; Catalán, P. Two approaches for the selection of Relevant Genetic Units for Conservation in the narrow European endemic steppe plant Boleum asperum (Brassicaceae). Biol. J. Linn. Soc. 2008, 94, 341-354. [CrossRef]

22. Médail, F.; Baumel, A. Using phylogeography to define conservation priorities: The case of narrow endemic plants in the Mediterranean Basin hotspot. Biol. Conserv. 2018, 224, 258-266. [CrossRef]

23. Salmerón-Sánchez, E.; Mendoza-Fernández, A.J.; Lorite, J.; Mota, J.F.; Peñas, J. Plant conservation in Mediterranean-type ecosystems. Mediterr. Bot. 2021, 42, e71333. [CrossRef]

24. Medail, F.; Quezel, P. Hot-Spots Analysis for Conservation of Plant Biodiversity in the Mediterranean Basin. Ann. Missouri Bot. Gard. 1997, 84, 112. [CrossRef]

25. Medail, F.; Quezel, P. Biodiversity hotspots in the Mediterranean Basin: Setting global conservation priorities. Conserv. Biol. 1999, 13, 1510-1513. [CrossRef]

26. Myers, N.; Mittermeier, R.A.; Mittermeier, C.G.; da Fonseca, G.A.B.; Kent, J. Biodiversity hotspots for conservation priorities. Nature 2000, 403, 853-858. [CrossRef] [PubMed]

27. Hoffman, M.; Koenig, K.; Bunting, G.; Costanza, J.; Williams, K.J. Biodiversity Hotspots (version 2016.1) (2016.1) [Data set] Zenodo 2016. [CrossRef]

28. Esler, K.J.; Jacobsen, A.L.; Pratt, R.B. The Biology of Mediterranean-Type Ecosystems; Oxford University Press: Oxford, UK, 2018; Volume 1, ISBN 9780198739135.

29. Hopper, S.D.; Gioia, P. The Southwest Australian Floristic Region: Evolution and Conservation of a Global Hot Spot of Biodiversity. Annu. Rev. Ecol. Evol. Syst. 2004, 35, 623-650. [CrossRef]

30. Graham, N.E.; Ammann, C.M.; Fleitmann, D.; Cobb, K.M.; Luterbacher, J. Support for global climate reorganization during the "Medieval Climate Anomaly". Clim. Dyn. 2011, 37, 1217-1245. [CrossRef]

31. Underwood, E.C.; Viers, J.H.; Klausmeyer, K.R.; Cox, R.L.; Shaw, M.R. Threats and biodiversity in the mediterranean biome. Divers. Distrib. 2009, 15, 188-197. [CrossRef] 
32. Archibold, O.W. Mediterranean Ecosystems: Ecology of World Vegetation; Chapman Hall: London, UK, 1995 ; ISBN 0412442906.

33. Schultz, J. The Ecozones of the World. The Ecological Divisions of the Geosphere; Springer: Berlin/Heidelberg, Germany, 1995; ISBN 9783662031612.

34. Cowling, R.M.; Ojeda, F.; Lamont, B.B.; Rundel, P.W.; Lechmere-Oertel, R. Rainfall reliability, a neglected factor in explaining convergence and divergence of plant traits in fire-prone mediterranean-climate ecosystems. Glob. Ecol. Biogeogr. 2005, 14, 509-519. [CrossRef]

35. Cowling, R.M.; MacDonald, I.A.W.; Simmons, M.T. The Cape Peninsula, South Africa: Physiographical, biological and historical background to an extraordinary hot-spot of biodiversity. Biodivers. Conserv. 1996, 5, 527-550. [CrossRef]

36. Linder, H.P. The radiation of the Cape flora, southern Africa. Biol. Rev. 2003, 78, S1464793103006171. [CrossRef]

37. Mendoza-Fernández, A.J.; Martínez-Hernández, F.; Salmerón-Sánchez, E.; Pérez-García, F.J.; Teruel, B.; Merlo, M.E.; Mota, J.F. The Relict Ecosystem of Maytenus senegalensis subsp. europaea in an Agricultural Landscape: Past, Present and Future Scenarios. Land 2020, 10, 1. [CrossRef]

38. Vargas, P.; Nogales, M.; Jaramillo, P.; Olesen, J.M.; Traveset, A.; Heleno, R. Plant colonization across the Galápagos Islands: Success of the sea dispersal syndrome. Bot. J. Linn. Soc. 2014, 174, 349-358. [CrossRef]

39. Verdú, M.; Dávila, P.; García-Fayos, P.; Flores-Hernández, N.; Valiente-Banuet, A. 'Convergent' traits of mediterranean woody plants belong to pre-mediterranean lineages. Biol. J. Linn. Soc. 2003, 78, 415-427. [CrossRef]

40. Valente, L.M.; Vargas, P. Contrasting evolutionary hypotheses between two mediterranean-climate floristic hotspots: The Cape of southern Africa and the Mediterranean Basin. J. Biogeogr. 2013, 40, 2032-2046. [CrossRef]

41. Rundel, P.W.; Arroyo, M.T.K.; Cowling, R.M.; Keeley, J.E.; Lamont, B.B.; Vargas, P. Mediterranean Biomes: Evolution of Their Vegetation, Floras, and Climate. Annu. Rev. Ecol. Evol. Syst. 2016, 47, 383-407. [CrossRef]

42. Mittermeier, R.A. Biodiversity Hotspots and Major Tropical Wilderness Areas: Approaches to Setting Conservation Priorities. Conserv. Biol. 1998, 12, 516-520. [CrossRef]

43. Harrison, S.; Noss, R. Endemism hotspots are linked to stable climatic refugia. Ann. Bot. 2017, 119, 207-214. [CrossRef]

44. Trew, B.T.; Maclean, I.M.D. Vulnerability of global biodiversity hotspots to climate change. Glob. Ecol. Biogeogr. 2021, 30, 768-783. [CrossRef]

45. Esler, D.; Ballachey, B.E.; Matkin, C.; Cushing, D.; Kaler, R.; Bodkin, J.; Monson, D.; Esslinger, G.; Kloecker, K. Timelines and mechanisms of wildlife population recovery following the Exxon Valdez oil spill. Deep Sea Res. Part II Top. Stud. Oceanogr. 2018, 147, 36-42. [CrossRef]

46. Sala, O.E.; Stuart Chapin, F., III; Armesto, J.J.; Berlow, E.; Bloomfield, J.; Dirzo, R.; Huber-Sanwald, E.; Huenneke, L.F.; Jackson, R.B.; Kinzig, A.; et al. Global Biodiversity Scenarios for the Year 2100. Science 2000, 287, 1770-1774. [CrossRef]

47. Lozano, F.D.; Atkins, K.J.; Moreno Sáiz, J.C.; Sims, A.E.; Dixon, K. The nature of threat category changes in three Mediterranean biodiversity hotspots. Biol. Conserv. 2013, 157, 21-30. [CrossRef]

48. Mendoza-Fernández, A.J.; Salmerón-Sánchez, E.; Lorite, J.; Mota, J.F.; Peñas, J. Plant Conservation Biology: A view from the Mediterranean ecoregions. Mediterr. Bot. 2021, 42, e71209. [CrossRef]

49. Moreira, F.; Allsopp, N.; Esler, K.J.; Wardell-Johnson, G.; Ancillotto, L.; Arianoutsou, M.; Clary, J.; Brotons, L.; Clavero, M.; Dimitrakopoulos, P.G.; et al. Priority questions for biodiversity conservation in the Mediterranean biome: Heterogeneous perspectives across continents and stakeholders. Conserv. Sci. Pract. 2019, 1, e118. [CrossRef]

50. Brooks, T.M.; Mittermeier, R.A.; da Fonseca, G.A.B.; Gerlach, J.; Hoffmann, M.; Lamoreux, J.F.; Mittermeier, C.G.; Pilgrim, J.D.; Rodrigues, A.S.L. Global Biodiversity Conservation Priorities. Science 2006, 313, 58-61. [CrossRef] [PubMed]

51. Cox, R.L.; Underwood, E.C. The Importance of Conserving Biodiversity Outside of Protected Areas in Mediterranean Ecosystems. PLOS ONE 2011, 6, e14508. [CrossRef]

52. Taberlet, P.; Fumagalli, L.; Wust-Saucy, A.G.; Cosson, J.F. Comparative phylogeography and postglacial colonization routes in Europe. Mol. Ecol. 1998, 7, 453-464. [CrossRef]

53. Comes, H.P.; Abbott, R.J. The relative importance of historical events and gene flow on the population structure of a mediterranean ragwort, Senecio gallicus (Asteraceae). Evolution 1998, 52, 355-367. [CrossRef]

54. Fois, M.; Cuena-Lombraña, A.; Bacchetta, G. Knowledge gaps and challenges for conservation of Mediterranean wetlands: Evidence from a comprehensive inventory and literature analysis for Sardinia. Aquat. Conserv. Mar. Freshw. Ecosyst. 2021, 31, 2621-2631. [CrossRef]

55. Massó, S.; López-Pujol, J.; Vilatersana, R. Reinterpretation of an endangered taxon based on integrative taxonomy: The case of Cynara baetica (Compositae). PLoS ONE 2018, 13, e0207094. [CrossRef] [PubMed]

56. Baumel, A.; Médail, F.; Juin, M.; Paquier, T.; Clares, M.; Laffargue, P.; Lutard, H.; Dixon, L.; Pires, M. Population genetic structure and management perspectives for Armeria belgenciencis, a narrow endemic plant from Provence (France). Plant Ecol. Evol. 2020, 153, 219-228. [CrossRef]

57. Jiang, T.; Pan, J.; Pu, X.-M.; Wang, B.; Pan, J.-J. Current status of coastal wetlands in China: Degradation, restoration, and future management. Estuar. Coast. Shelf Sci. 2015, 164, 265-275. [CrossRef]

58. Bobo-Pinilla, J.; Barrios de León, S.B.; Seguí Colomar, J.; Fenu, G.; Bacchetta, G.; Peñas, J.; Martínez-Ortega, M.M. Phylogeography of Arenaria balearica L. (Caryophyllaceae): Evolutionary history of a disjunct endemic from the Western Mediterranean continental islands. PeerJ 2016, 4, e2618. [CrossRef] [PubMed] 
59. Alipour, S.; Yousefzadeh, H.; Badehian, Z.; Asadi, F.; Espahbodi, K.; Dering, M. Genetic diversity and structure of the endemic and critically endangered Populus caspica in the Hyrcanian forests. Tree Genet. Genomes 2021, 17, 19. [CrossRef]

60. Engelhardt, K.A.M.; Lloyd, M.W.; Neel, M.C. Effects of genetic diversity on conservation and restoration potential at individual, population, and regional scales. Biol. Conserv. 2014, 179, 6-16. [CrossRef]

61. Thompson, J.D. Plant Evolution in the Mediterranean; Oxford University Press: Oxford, UK, 2005; ISBN 9780198515340.

62. Habel, J.C.; Zachos, F.E.; Dapporto, L.; Rödder, D.; Radespiel, U.; Tellier, A.; Schmitt, T. Population genetics revisited-towards a multidisciplinary research field. Biol. J. Linn. Soc. 2015, 115, 1-12. [CrossRef]

63. Diniz-Filho, J.A.F.; Bini, L.M. Geographical Patterns in Biodiversity: Towards an Integration of Concepts and Methods from Genes to Species Diversity. Nat. Conserv. 2011, 9, 179-187. [CrossRef]

64. Avise, J.C.; Bowen, B.W.; Ayala, F.J. In the light of evolution X: Comparative phylogeography. Proc. Natl. Acad. Sci. USA 2016, 113, 7957-7961. [CrossRef] [PubMed]

65. Lexer, C.; Mangili, S.; Bossolini, E.; Forest, F.; Stölting, K.N.; Pearman, P.B.; Zimmermann, N.E.; Salamin, N. 'Next generation' biogeography: Towards understanding the drivers of species diversification and persistence. J. Biogeogr. 2013, 40, 1013-1022. [CrossRef]

66. Prentice, H.C.; Ursula Malm, J.; Mateu-Andrés, I. Allozyme and chloroplast DNA variation in island and mainland populations of the rare Spanish endemic, Silene hifacensis (Caryophyllaceae). Conserv. Genet. 2003, 4, 543-555. [CrossRef]

67. Hampe, A.; Petit, R.J. Conserving biodiversity under climate change: The rear edge matters. Ecol. Lett. 2005, 8, 461-467. [CrossRef]

68. Mota, J.F.; Sola, A.J.; Jiménez-Sánchez, M.L.; Pérez-García, F.; Merlo, M.E. Gypsicolous flora, conservation and restoration of quarries in the southeast of the Iberian Peninsula. Biodivers. Conserv. 2004, 13, 1797-1808. [CrossRef]

69. Aitken, S.N.; Whitlock, M.C. Assisted Gene Flow to Facilitate Local Adaptation to Climate Change. Annu. Rev. Ecol. Evol. Syst. 2013, 44, 367-388. [CrossRef]

70. Breed, M.F.; Stead, M.G.; Ottewell, K.M.; Gardner, M.G.; Lowe, A.J. Which provenance and where? Seed sourcing strategies for revegetation in a changing environment. Conserv. Genet. 2013, 14, 1-10. [CrossRef]

71. Hausdorf, B. Progress toward a general species concept. Evolution 2011, 65, 923-931. [CrossRef] [PubMed]

72. Duminil, J.; Di Michele, M. Plant species delimitation: A comparison of morphological and molecular markers. Plant Biosyst. 2009, 143, 528-542. [CrossRef]

73. Mace, G.M. The role of taxonomy in species conservation. Philos. Trans. R. Soc. London. Ser. B Biol. Sci. 2004, 359, 711-719. [CrossRef]

74. IUCN. Guidelines for Re-Introductions; IUCN: Gland, Switzerland; Cambridge, UK, 1998; ISBN 2831704480.

75. Frankham, R.; Ballou, J.D.; Dudash, M.R.; Eldridge, M.D.B.; Fenster, C.B.; Lacy, R.C.; Mendelson, J.R.; Porton, I.J.; Ralls, K.; Ryder, O.A. Implications of different species concepts for conserving biodiversity. Biol. Conserv. 2012, 153, 25-31. [CrossRef]

76. Nybom, H. Comparison of different nuclear DNA markers for estimating intraspecific genetic diversity in plants. Mol. Ecol. 2004, 13, 1143-1155. [CrossRef]

77. Srivastava, D.S.; Cadotte, M.W.; MacDonald, A.A.M.; Marushia, R.G.; Mirotchnick, N. Phylogenetic diversity and the functioning of ecosystems. Ecol. Lett. 2012, 15, 637-648. [CrossRef]

78. Winter, M.; Devictor, V.; Schweiger, O. Phylogenetic diversity and nature conservation: Where are we? Trends Ecol. Evol. 2013, 28, 199-204. [CrossRef]

79. Rumeu, B.; Vargas, P.; Jaén-Molina, R.; Nogales, M.; Caujapé-Castells, J. Phylogeography and genetic structure of the threatened Canarian Juniperus cedrus (Cupressaceae). Bot. J. Linn. Soc. 2014, 175, 376-394. [CrossRef]

80. Avise, J.C. Gene trees and organismal histories: A phylogenetic approach to population biology. Evolution 1989, 43, 1192-1208. [CrossRef]

81. Casacci, L.P.; Barbero, F.; Balletto, E. The "Evolutionarily Significant Unit" concept and its applicability in biological conservation. Ital. J. Zool. 2014, 81, 182-193. [CrossRef]

82. Avise, J.C. Molecular Markers, Natural History and Evolution; Springer: Boston, MA, USA, 1994; ISBN 978-0-412-03781-8.

83. Fraser, D.J.; Bernatchez, L. Adaptive evolutionary conservation: Towards a unified concept for defining conservation units. Mol. Ecol. 2001, 10, 2741-2752. [CrossRef] [PubMed]

84. Dizon, A.E.; Lockyer, C.; Perrin, W.F.; Demaster, D.P.; Sisson, J. Rethinking the Stock Concept: A Phylogeographic Approach. Conserv. Biol. 1992, 6, 24-36. [CrossRef]

85. Bowen, B.W.; Clark, A.M.; Abreu-Grobois, F.A.; Chaves, A.; Reichart, H.A.; Ferl, R.J. Global phylogeography of the ridley sea turtles (Lepidochelys spp.) as inferred from mitochondrial DNA sequences. Genetica 1998, 101, 179-189. [CrossRef]

86. Crandall, K.A.; Bininda-Emonds, O.R.P.; Mace, G.M.; Wayne, R.K. Considering evolutionary processes in conservation biology. Trends Ecol. Evol. 2000, 15, 290-295. [CrossRef]

87. Vogler, A.P.; Desalle, R. Diagnosing Units of Conservation Management. Conserv. Biol. 1994, 8, 354-363. [CrossRef]

88. Waples, R.S. Pacific salmon, Oncorhynchus spp., and the definition of "species" under the Endangered Species Act. Mar. Fish. Rev. 1991, 53, 11.

89. De Guia, A.P.O.; Saitoh, T. The gap between the concept and definitions in the Evolutionarily Significant Unit: The need to integrate neutral genetic variation and adaptive variation. Ecol. Res. 2007, 22, 604-612. [CrossRef]

90. Doadrio, I.; Perdices, A.; Machordom, A. Allozymic variation of the endangered killifish Aphanius iberus and its application to conservation. Environ. Biol. Fishes 1996, 45, 259-271. [CrossRef] 
91. Corral-Lou, A.; Perea, S.; Doadrio, I. High genetic differentiation in the endemic and endangered freshwater fish Achondrostoma salmantinum. Conserv. Genet. 2021, 22, 585-600. [CrossRef]

92. Eizirik, E.; Kim, J.-H.; Menotti-Raymond, M.; Crawshaw, P.G., Jr.; O’Brien, S.J.; Johnson, W.E. Phylogeography, population history and conservation genetics of jaguars (Panthera onca, Mammalia, Felidae). Mol. Ecol. 2001, 10, 65-79. [CrossRef] [PubMed]

93. Sarasola-Puente, V.; Madeira, M.J.; Gosá, A.; Lizana, M.; Gómez-Moliner, B. Population structure and genetic diversity of Rana dalmatina in the Iberian Peninsula. Conserv. Genet. 2012, 13, 197-209. [CrossRef]

94. Frankham, R.; Ballou, J.D.; Briscoe, D.A. Introduction to Conservation Genetics, 2nd ed.; Cambridge University Press: Cambridge, UK, 2010; ISBN 9780521702713.

95. Bengtsson, B.O.; Weibull, P.; Ghatnekar, L. The loss of alleles by sampling: A study of the common outbreeding grass Festuca ovina over three geographic scales. Hereditas 1995, 122, 221-238. [CrossRef]

96. Lopez, S.; Rousset, F.Ç.; Shaw, F.H.; Shaw, R.G.; Ronce, O. Joint effects of inbreeding and local adaptation on the evolution of genetic load after fragmentation. Conserv. Biol. 2009, 23, 1618-1627. [CrossRef]

97. Shaw, R.G.; Etterson, J.R. Rapid climate change and the rate of adaptation: Insight from experimental quantitative genetics. New Phytol. 2012, 195, 752-765. [CrossRef]

98. Mee, J.A.; Bernatchez, L.; Reist, J.D.; Rogers, S.M.; Taylor, E.B. Identifying designatable units for intraspecific conservation prioritization: A hierarchical approach applied to the lake whitefish species complex (Coregonus spp.). Evol. Appl. 2015, 8, 423-441. [CrossRef]

99. Semaan, M.T.; Dodd, R.S. Genetic variability and structure of the remnant natural populations of Cedrus libani (Pinaceae) of Lebanon. Tree Genet. Genomes 2008, 4, 757-766. [CrossRef]

100. Szövényi, P.; Ricca, M.; Shaw, A.J. Multiple paternity and sporophytic inbreeding depression in a dioicous moss species. Heredity 2009, 103, 394-403. [CrossRef]

101. Wahid, N.; Naydenov, K.D.; Kamari, S.; Boulli, A.; Tremblay, F. Genetic structure of Pinus pinaster Ait. populations in Morocco revealed by nuclear microsatellites. Biochem. Syst. Ecol. 2010, 38, 73-82. [CrossRef]

102. Boulila, A.; Béjaoui, A.; Messaoud, C.; Boussaid, M. Genetic Diversity and Population Structure of Teucrium polium (Lamiaceae) in Tunisia. Biochem. Genet. 2010, 48, 57-70. [CrossRef] [PubMed]

103. Belletti, P.; Ferrazzini, D.; Piotti, A.; Monteleone, I.; Ducci, F. Genetic variation and divergence in Scots pine (Pinus sylvestris L.) within its natural range in Italy. Eur. J. For. Res. 2012, 131, 1127-1138. [CrossRef]

104. Pellegrino, G.; Bellusci, F. Effects of human disturbance on reproductive success and population viability of Serapias cordigera (Orchidaceae). Bot. J. Linn. Soc. 2014, 176, 408-420. [CrossRef]

105. Mucciarelli, M.; Ferrazzini, D.; Belletti, P. Genetic Variability and Population Divergence in the Rare Fritillaria tubiformis subsp. moggridgei Rix (Liliaceae) as Revealed by RAPD Analysis. PLoS ONE 2014, 9, e101967. [CrossRef] [PubMed]

106. Hardion, L.; Verlaque, R.; Saltonstall, K.; Leriche, A.; Vila, B. Origin of the invasive Arundo donax (Poaceae): A trans-Asian expedition in herbaria. Ann. Bot. 2014, 114, 455-462. [CrossRef] [PubMed]

107. Bacchetta, G.; Bueno Sánchez, A.; Fenu, G.; Jiménez-Alfaro, B.; Mattana, E.; Piotto, B.; Virevaire, M. (Eds.) Conservación Ex Situ de Plantas Silvestres; Principado de Asturias/La Caixa: Gijón, Spain, 2008.

108. Sarasan, V.; Cripps, R.; Ramsay, M.M.; Atherton, C.; McMichen, M.; Prendergast, G.; Rowntree, J.K. Conservation In vitro of threatened plants-Progress in the past decade. Vitr. Cell. Dev. Biol.-Plant 2006, 42, 206-214. [CrossRef]

109. Hufford, K.M.; Mazer, S.J. Plant ecotypes: Genetic differentiation in the age of ecological restoration. Trends Ecol. Evol. 2003, 18, 147-155. [CrossRef]

110. Godefroid, S.; Piazza, C.; Rossi, G.; Buord, S.; Stevens, A.-D.; Aguraiuja, R.; Cowell, C.; Weekley, C.W.; Vogg, G.; Iriondo, J.M.; et al. How successful are plant species reintroductions? Biol. Conserv. 2011, 144, 672-682. [CrossRef]

111. Volis, S. Conservation meets restoration-rescuing threatened plant species by restoring their environments and restoring environments using threatened plant species. Isr. J. Plant Sci. 2016, 63, 262-275. [CrossRef]

112. Mistretta, O. Genetics of species re-introductions: Applications of genetic analysis. Biodivers. Conserv. 1994, 3, 184-190. [CrossRef]

113. McKay, J.K.; Christian, C.E.; Harrison, S.; Rice, K.J. “How Local Is Local?"-A Review of Practical and Conceptual Issues in the Genetics of Restoration. Restor. Ecol. 2005, 13, 432-440. [CrossRef]

114. Falk, D.A. Process-centred restoration in a fire-adapted ponderosa pine forest. J. Nat. Conserv. 2006, 14, 140-151. [CrossRef]

115. Vander Mijnsbrugge, K.; Bischoff, A.; Smith, B. A question of origin: Where and how to collect seed for ecological restoration. Basic Appl. Ecol. 2010, 11, 300-311. [CrossRef]

116. Fenu, G.; Bacchetta, G.; Charalambos, S.C.; Fournaraki, C.; del Galdo, G.P.G.; Gotsiou, P.; Kyratzis, A.; Piazza, C.; Vicens, M.; Pinna, M.S.; et al. An early evaluation of translocation actions for endangered plant species on Mediterranean islands. Plant Divers. 2019, 41, 94-104. [CrossRef] [PubMed]

117. Caujapé-Castells, J.; Pedrola-Monfort, J. Designing ex-situ conservation strategies through the assessment of neutral genetic markers: Application to the endangered Androcymbium gramineum. Conserv. Genet. 2004, 5, 131-144. [CrossRef]

118. Batista, F.; Bañares, A.; Caujapé-Castells, J.; Carqué, E.; Marrero-Gómez, M.; Sosa, P.A. Allozyme diversity in three endemic species of Cistus (Cistaceae) from the Canary Islands: Intraspecific and interspecific comparisons and implications for genetic conservation. Am. J. Bot. 2001, 88, 1582-1592. [CrossRef] [PubMed]

119. Kirk, H.; Freeland, J.R. Applications and Implications of Neutral versus Non-neutral Markers in Molecular Ecology. Int. J. Mol. Sci. 2011, 12, 3966-3988. [CrossRef] 
120. Ciofi, C.; Bruford, M.W. Genetic structure and gene flow among Komodo dragon populations inferredby microsatellite loci analysis. Mol. Ecol. 1999, 8, S17-S30. [CrossRef]

121. Knapp, E.; Rice, K. Starting from Seed: Genetic Issues in Using Native Grasses for Restoration. Ecol. Restor. 1994, $12,40-45$. [CrossRef]

122. Chung, M.Y.; Son, S.; Mao, K.; López-Pujol, J.; Chung, M.G. Seed collection strategies for plant restoration with the aid of neutral genetic diversity. Korean J. Plant Taxon. 2019, 49, 275-281. [CrossRef]

123. Krauss, S.L.; Koch, J.M. Methodological insights: Rapid genetic delineation of provenance for plant community restoration. J. Appl. Ecol. 2004, 41, 1162-1173. [CrossRef]

124. Krauss, S.L.; He, T.H. Rapid genetic identification of local provenance seed collection zones for ecological restoration and biodiversity conservation. J. Nat. Conserv. 2006, 14, 190-199. [CrossRef]

125. Hubert, J.; Cottrell, J. The Role of Forest Genetic Resources in Helping British Forests; Forestry Commission: Edinburgh, Scotland, 2004.

126. Bobo-Pinilla, J.; Salmerón-Sánchez, E.; Mota, J.F.; Peñas, J. Genetic conservation strategies of endemic plants from edaphic habitat islands: The case of Jacobaea auricula (Asteraceae). J. Nat. Conserv. 2021, 61, 126004. [CrossRef]

127. Bobo Pinilla, J.; López-González, N.; Caballero, A.; Peñas de Giles, J. Looking for a successful translocation: The case of Astragalus edulis. Mediterr. Bot. 2021, 42, e68048. [CrossRef]

128. Friar, E.A.; Ladoux, T.; Roalson, E.H.; Robichaux, R.H. Microsatellite analysis of a population crash and bottleneck in the Mauna Kea silversword, Argyroxiphium sandwicense ssp. sandwicense (Asteraceae), and its implications for reintroduction. Mol. Ecol. 2000, 9, 2027-2034. [CrossRef]

129. Armstrong, D.P.; Seddon, P.J. Directions in reintroduction biology. Trends Ecol. Evol. 2008, 23, 20-25. [CrossRef]

130. Barrett, S.C.H.; Kohn, J.R. Genetic and evolutionary consequences of small population sizes in plants: Implications for conservation. In Genetics and Conservation of Rare Plants; Falk, D.A., Holsinger, K.A., Eds.; Oxford University Press: New York, NY, USA, 1991; pp. 3-30. ISBN 9780195064292.

131. Fenster, C.B.; Galloway, L.F. Inbreeding and outbreeding depression in natural populations of Chamaecrista fasciculata (Fabaceae). Conserv. Biol. 2000, 14, 1406-1412. [CrossRef]

132. Young, T.P.; Petersen, D.A.; Clary, J.J. The ecology of restoration: Historical links, emerging issues and unexplored realms. Ecol. Lett. 2005, 8, 662-673. [CrossRef]

133. Young, A.G.; Clarke, G.M. Genetics, Demography and Viability of Fragmented Populations; Cambridge University Press: London, UK, 2000; ISBN 9780521782074.

134. Frankham, R. Genetics and extinction. Biol. Conserv. 2005, 126, 131-140. [CrossRef]

135. Frankham, R.; Ballou, J.D.; Briscoe, D.A.; McInnes, K.H. Introduction to Conservation Genetics; Cambridge University Press: Cambridge, UK, 2002; ISBN 9780511808999.

136. Broadhurst, L.M.; Lowe, A.; Coates, D.J.; Cunningham, S.A.; McDonald, M.; Vesk, P.A.; Yates, C. Seed supply for broadscale restoration: Maximizing evolutionary potential. Evol. Appl. 2008, 1, 587-597. [CrossRef]

137. Nieto Feliner, G. Patterns and processes in plant phylogeography in the Mediterranean Basin. A review. Perspect. Plant Ecol. Evol. Syst. 2014, 16, 265-278. [CrossRef]

138. Segarra-Moragues, J.G.; Palop-Esteban, M.; González-Candelas, F.; Catalán, P. On the verge of extinction: Genetics of the critically endangered Iberian plant species, Borderea chouardii (Dioscoreaceae) and implications for conservation management. Mol. Ecol. 2005, 14, 969-982. [CrossRef] [PubMed]

139. Mueller, U.G.; Wolfenbarger, L.L. AFLP genotyping and fingerprinting. Trends Ecol. Evol. 1999, 14, 389-394. [CrossRef]

140. Agrimonti, C.; Bianchi, R.; Bianchi, A.; Ballero, M.; Poli, F.; Marmiroli, N. Understanding biological conservation strategies: A molecular-genetic approach to the case of myrtle (Myrtus communis L.) in two Italian regions: Sardinia and Calabria. Conserv. Genet. 2007, 8, 385-396. [CrossRef]

141. Segarra-Moragues, J.G.; Catalán, P. The fewer and the better: Prioritization of populations for conservation under limited resources, a genetic study with Borderea pyrenaica (Dioscoreaceae) in the Pyrenean National Park. Genetica 2010, 138, 363-376. [CrossRef] [PubMed]

142. Chen, F.; Wang, A.; Chen, K.; Wan, D.; Liu, J. Genetic diversity and population structure of the endangered and medically important Rheum tanguticum (Polygonaceae) revealed by SSR Markers. Biochem. Syst. Ecol. 2009, 37, 613-621. [CrossRef]

143. Garcia-Jacas, N.; Requena, J.; Massó, S.; Vilatersana, R.; Blanché, C.; López-Pujol, J. Genetic diversity and structure of the narrow endemic Seseli farrenyi (Apiaceae): Implications for translocation. PeerJ 2021, 9, e10521. [CrossRef]

144. Juan, A.; Fay, M.F.; Pastor, J.; Juan, R.; Fernández, I.; Crespo, M.B. Genetic structure and phylogeography in Juniperus oxycedrus subsp. macrocarpa around the Mediterranean and Atlantic coasts of the Iberian Peninsula, based on AFLP and plastid markers. Eur. J. For. Res. 2012, 131, 845-856. [CrossRef]

145. Salmerón-Sánchez, E.; Merlo, M.E.; Medina-Cazorla, J.M.; Pérez-García, F.J.; Martínez-Hernández, F.; Garrido-Becerra, J.A.; Mendoza-Fernández, A.J.; Valle, F.; Mota, J.F. Variability, genetic structure and phylogeography of the dolomitophilous species Convolvulus boissieri (Convolvulaceae) in the Baetic ranges, inferred from AFLPs, plastid DNA and ITS sequences. Bot. J. Linn. Soc. 2014, 176, 506-523. [CrossRef]

146. Salmerón-Sánchez, E.; Martínez-Ortega, M.M.; Mota, J.F.; Peñas, J. A complex history of edaphic habitat islands in the Iberian Peninsula: Phylogeography of the halo-gypsophyte Jacobaea auricula (Asteraceae). Bot. J. Linn. Soc. 2017, 185, 376-392. [CrossRef] 
147. Gutierrez Larena, B.; Fuertes Aguilar, J.; Nieto Feliner, G. Glacial-induced altitudinal migrations in Armeria (Plumbaginaceae) inferred from patterns of chloroplast DNA haplotype sharing. Mol. Ecol. 2002, 11, 1965-1974. [CrossRef] [PubMed]

148. Kropf, M.; Kadereit, J.W.; Comes, H.P. Differential cycles of range contraction and expansion in European high mountain plants during the Late Quaternary: Insights from Pritzelago alpina (L.) O. Kuntze (Brassicaceae). Mol. Ecol. 2003, 12, 931-949. [CrossRef] [PubMed]

149. Aguilar, J.F.; Rosselló, J.A.; Feliner, G.N. Molecular evidence for the compilospecies model of reticulate evolution in Armeria (Plumbaginaceae). Syst. Biol. 1999, 48, 735-754. [CrossRef]

150. Emerson, K.J.; Merz, C.R.; Catchen, J.M.; Hohenlohe, P.A.; Cresko, W.A.; Bradshaw, W.E.; Holzapfel, C.M. Resolving postglacial phylogeography using high-throughput sequencing. Proc. Natl. Acad. Sci. USA 2010, 107, 16196-16200. [CrossRef] [PubMed]

151. Kirschner, P.; Arthofer, W.; Pfeifenberger, S.; Záveská, E.; Schönswetter, P.; Frajman, B.; Gamisch, A.; Hilpold, A.; Paun, O.; Sanmartín, I.; et al. Performance comparison of two reduced-representation based genome-wide marker-discovery strategies in a multi-taxon phylogeographic framework. Sci. Rep. 2021, 11, 3978. [CrossRef] [PubMed]

152. Onley, I.R.; Moseby, K.E.; Austin, J.J. Genomic approaches for conservation management in australia under climate change. Life 2021, 11, 653. [CrossRef]

153. Coates, D.J.; Byrne, M.; Moritz, C. Genetic diversity and conservation units: Dealing with the species-population continuum in the age of genomics. Front. Ecol. Evol. 2018, 6, 165. [CrossRef]

154. Bickford, D.; Lohman, D.J.; Sodhi, N.S.; Ng, P.K.L.; Meier, R.; Winker, K.; Ingram, K.K.; Das, I. Cryptic species as a window on diversity and conservation. Trends Ecol. Evol. 2007, 22, 148-155. [CrossRef]

155. Jörger, K.M.; Schrödl, M. How to describe a cryptic species? Practical challenges of molecular taxonomy. Front. Zool. 2013, 10, 59. [CrossRef]

156. Struck, T.H.; Feder, J.L.; Bendiksby, M.; Birkeland, S.; Cerca, J.; Gusarov, V.I.; Kistenich, S.; Larsson, K.-H.; Liow, L.H.; Nowak, M.D.; et al. Finding Evolutionary Processes Hidden in Cryptic Species. Trends Ecol. Evol. 2018, 33, 153-163. [CrossRef]

157. Mallet, J. Hybrid speciation. Nature 2007, 446, 279-283. [CrossRef] [PubMed]

158. Rieseberg, L.H.; Willis, J.H. Plant Speciation. Science 2007, 317, 910-914. [CrossRef] [PubMed]

159. Arnold, M.L.; Kunte, K. Adaptive Genetic Exchange: A Tangled History of Admixture and Evolutionary Innovation. Trends Ecol. Evol. 2017, 32, 601-611. [CrossRef] [PubMed]

160. Ottenlips, M.V.; Mansfield, D.H.; Buerki, S.; Feist, M.A.E.; Downie, S.R.; Dodsworth, S.; Forest, F.; Plunkett, G.M.; Smith, J.F. Resolving species boundaries in a recent radiation with the Angiosperms353 probe set: The Lomatium packardiae/L. anomalum clade of the L. triternatum (Apiaceae) complex. Am. J. Bot. 2021, 108, 1217-1233. [CrossRef]

161. Milano, E.R.; Mulligan, M.R.; Rebman, J.P.; Vandergast, A.G. High-throughput sequencing reveals distinct regional genetic structure among remaining populations of an endangered salt marsh plant in California. Conserv. Genet. 2020, 21, 547-559. [CrossRef]

162. Burge, D.O.; Rebman, J.P.; Mulligan, M.R.; Wilken, D.H. Three Edaphic-Endemic Ceanothus (Rhamnaceae) New to Science. Syst. Bot. 2017, 42, 529-542. [CrossRef]

163. Fuentes, G.; González, F.; Saavedra, J.; López-Sepúlveda, P.; Victoriano, P.F.; Stuessy, T.F.; Ruiz-Ponce, E. Assessing signals of selection and historical demography to develop conservation strategies in the Chilean emblematic Araucaria araucana. Sci. Rep. 2021, 11, 20504. [CrossRef]

164. Wood, G.; Marzinelli, E.M.; Campbell, A.H.; Steinberg, P.D.; Vergés, A.; Coleman, M.A. Genomic vulnerability of a dominant seaweed points to future-proofing pathways for Australia's underwater forests. Glob. Chang. Biol. 2021, 27, 2200-2212. [CrossRef]

165. Lim, S.L.; D'Agui, H.M.; Enright, N.J.; He, T. Characterization of Leaf Transcriptome in Banksia hookeriana. Genomics. Proteom. Bioinform. 2017, 15, 49-56. [CrossRef]

166. Steane, D.A.; Potts, B.M.; McLean, E.H.; Collins, L.; Holland, B.R.; Prober, S.M.; Stock, W.D.; Vaillancourt, R.E.; Byrne, M. Genomic Scans across Three Eucalypts Suggest that Adaptation to Aridity is a Genome-Wide Phenomenon. Genome Biol. Evol. 2017, 9, 253-265. [CrossRef]

167. Supple, M.A.; Bragg, J.G.; Broadhurst, L.M.; Nicotra, A.B.; Byrne, M.; Andrew, R.L.; Widdup, A.; Aitken, N.C.; Borevitz, J.O. Landscape genomic prediction for restoration of a Eucalyptus foundation species under climate change. eLife 2018, 7, e31835. [CrossRef] [PubMed]

168. Pickup, M.; Field, D.L.; Rowell, D.M.; Young, A.G. Source population characteristics affect heterosis following genetic rescue of fragmented plant populations. Proc. R. Soc. B Biol. Sci. 2013, 280. [CrossRef] [PubMed]

169. Rey, O.; Eizaguirre, C.; Angers, B.; Baltazar-Soares, M.; Sagonas, K.; Prunier, J.G.; Blanchet, S. Linking epigenetics and biological conservation: Towards a conservation epigenetics perspective. Funct. Ecol. 2020, 34, 414-427. [CrossRef]

170. Baldwin, B.G. Fine-Scale to Flora-Wide Phylogenetic Perspectives on Californian Plant Diversity, Endemism, and Conservation. Ann. Missouri Bot. Gard. 2019, 104, 429-440. [CrossRef]

171. Kling, M.M.; Mishler, B.D.; Thornhill, A.H.; Baldwin, B.G.; Ackerly, D.D. Facets of phylodiversity: Evolutionary diversification, divergence and survival as conservation targets. Philos. Trans. R. Soc. B 2019, 374, 20170397. [CrossRef] [PubMed]

172. Elith, J.; Leathwick, J.R. Species distribution models: Ecological explanation and prediction across space and time. Annu. Rev. Ecol. Evol. Syst. 2009, 40, 677-697. [CrossRef]

173. López-González, N.; Bobo-Pinilla, J.; Gutiérrez-Larruscain, D.; Montserrat Martínez-Ortega, M.; Rojas-Andrés, B.M. Hybridization as a biodiversity driver: The case of Veronica $\times$ gundisalvi. Mediterr. Bot. 2021, 42, e67901. [CrossRef] 
174. Menon, S.; Choudhury, B.; Khan, M.; Townsend Peterson, A. Ecological niche modeling and local knowledge predict new populations of Gymnocladus assamicus a critically endangered tree species. Endanger. Species Res. 2010, 11, 175-181. [CrossRef]

175. Sarkinen, T.; Gonzáles, P.; Knapp, S. Distribution models and species discovery: The story of a new Solanum species from the Peruvian Andes. PhytoKeys 2013, 31, 1. [CrossRef]

176. Fois, M.; Cuena-Lombraña, A.; Fenu, G.; Bacchetta, G. Using species distribution models at local scale to guide the search of poorly known species: Review, methodological issues and future directions. Ecol. Modell. 2018, 385, 124-132. [CrossRef]

177. Park, D.S.; Ellison, A.M.; Davis, C.C. Mating system does not predict niche breath. Glob. Ecol. Biogeogr. 2018, 27, 804-813. [CrossRef]

178. Pearman, P.B.; D'Amen, M.; Graham, C.H.; Thuiller, W.; Zimmermann, N.E. Within-taxon niche structure: Niche conservatism, divergence and predicted effects of climate change. Ecography 2010, 33, 990-1003. [CrossRef]

179. Bálint, M.; Domisch, S.; Engelhardt, C.H.M.; Haase, P.; Lehrian, S.; Sauer, J.; Theissinger, K.; Pauls, S.U.; Nowak, C. Cryptic biodiversity loss linked to global climate change. Nat. Clim. Chang. 2011, 1, 313-318. [CrossRef]

180. Bendiksby, M.; Mazzoni, S.; Jørgensen, M.H.; Halvorsen, R.; Holien, H. Combining genetic analyses of archived specimens with distribution modelling to explain the anomalous distribution of the rare lichen Staurolemma omphalarioides: Long-distance dispersal or vicariance? J. Biogeogr. 2014, 41, 2020-2031. [CrossRef]

181. Chen, G.; Kéry, M.; Plattner, M.; Ma, K.; Gardner, B. Imperfect detection is the rule rather than the exception in plant distribution studies. J. Ecol. 2013, 101, 183-191. [CrossRef]

182. Tang, Y.; Winkler, J.A.; Viña, A.; Liu, J.; Zhang, Y.; Zhang, X.; Li, X.; Wang, F.; Zhang, J.; Zhao, Z. Uncertainty of future projections of species distributions in mountainous regions. PLoS ONE 2018, 13, e0189496. [CrossRef]

183. Cho, N.; Kim, E.; Lee, B.; Lim, J.; Kang, S. Predicting the Potential Distribution of Pinus densiflora and Analyzing the Relationship with Environmental Variable Using MaxEnt Model. Korean J. Agric. For. Meteorol. 2020, 22, 47-56. [CrossRef]

184. Han, E.K.; Cho, W.B.; Park, J.S.; Choi, I.S.; Kwak, M.; Kim, B.Y.; Lee, J.H. A Disjunctive Marginal Edge of Evergreen Broad-Leaved Oak (Quercus gilva) in East Asia: The High Genetic Distinctiveness and Unusual Diversity of Jeju Island Populations and Insight into a Massive, Independent Postglacial Colonization. Genes 2020, 11, 1114. [CrossRef]

185. Nualart, N.; Herrando-Moraira, S.; Cires, E.; Guardiola, M.; Laguna, E.; Pérez-Prieto, D.; Sáez, L.; López-Pujol, J. Reusing old and producing new data is useful for species delimitation in the taxonomically controversial iberian endemic pair Petrocoptis montsicciana/ P. pardoi (caryophyllaceae). Diversity 2021, 13, 205. [CrossRef]

186. Nygaard, M.; Kemppainen, P.; Speed, J.D.M.; Elven, R.; Flatberg, K.I.; Galten, L.P.; Yousefi, N.; Solstad, H.; Bendiksby, M. Combining population genomics and ecological niche modeling to assess taxon limits between Carex jemtlandica and C. lepidocarpa. J. Syst. Evol. 2021, 59, 627-641. [CrossRef] 